\section{$\Delta$ rkivoc

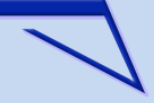

Archive for

Organic Chemistry
The Free Internet Journal

for Organic Chemistry
Paper

Arkivoc 2019, part vi, 459-480

\title{
Synthesis and in vitro anticancer evaluation of novel pyridine derivatives bearing tetrahydronaphthalene scaffold
}

Eman Kh. Hamza, ${ }^{a}$ Nehal A. Hamdy, ${ }^{a *}$ Eman S. Zarie, ${ }^{a}$ Issa M. I. Fakhr, ${ }^{a}$ Ahmed H. M. Elwahy, ${ }^{b}$ and Hanem M. Awad $^{a}$

${ }^{a}$ National Research Centre, El-Buhouth St., Dokki, P.O. 12622, Giza, Egypt

${ }^{b}$ Department of Chemistry, Faculty of Science, Cairo University, Giza, Egypt

E-mail: drnehalhamdy63@hotmail.com

Received 09-05-2019

Accepted 02-06-2020

Published on line $02-16-2020$

\section{Abstract}

A new series of tetralin-pyridine hybrids was synthesized in good yields starting from 2-(pyridin-2yl)oxy)acetohydrazide as a synthon. The treatment of this acid hydrazide with six different aromatic aldehydes resulted in the formation of the corresponding arylidenehydrazides as cis/trans conformers, which upon treatment with thioglycolic acid afforded 4-thiazolidinone derivatives. The acid hydrazide synthon also reacted with a variety of activated reagents to give the corresponding tetralin-pyridine derivatives in good yields. The in vitro cytotoxic activity of the new compounds were tested showing that these compounds appeared as promising active anti-cancer compounds.

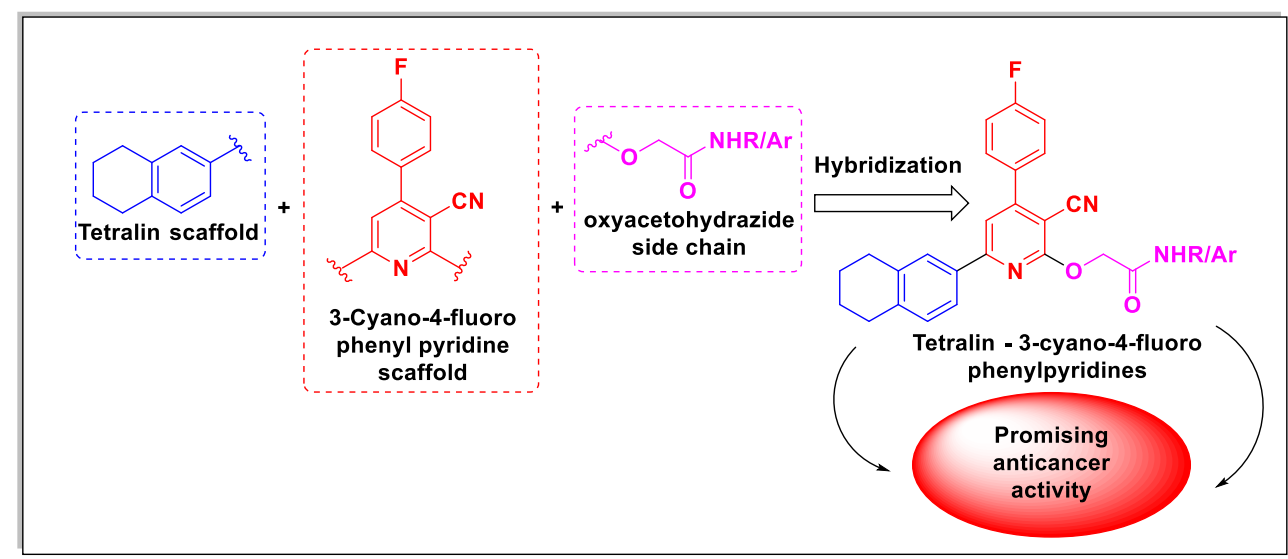

Keywords: Tetralin, pyridine, benzylidenehydrazides, thiazolidinones, anticancer activity 


\section{Introduction}

Cancer diseases are considered as the second common cause of death after heart disease worldwide..$^{1,2}$ Chemotherapy is still one of the most important roles for cancer treatment. The major issue in the use of chemotherapeutics is the undesirable side effects. Therefore, search for new agents, not only for the treatment of cancer but also to overcome cancer resistance to drug treatment as well as to avoid drug side effects, is a challenge goal.

In this respect, many pyridine derivatives have been synthesized and their biological and chemotherapeutic activities have been investigated and reported. ${ }^{3-6}$ The pyridine moiety is found in many pharmaceutical drugs such as Isoniazid (anti-tuberculosis drug), Omeprazole (antihistaminic drug), Pioglitazone (anti-diabetic drug), Sorafenib and Regorafenib (anticancer drugs) as well as in many agrochemicals such as pyridinenitrile (fungicide), Nitapyrin (bactericide) and Picloram (herbicide). The pyridine motif is also present in a number of biologically active molecules including niacin (vitamin B3), pyridoxine (vitamin B6) and the toxic alkaloid (nicotine) (Figure 1). ${ }^{7-11}$

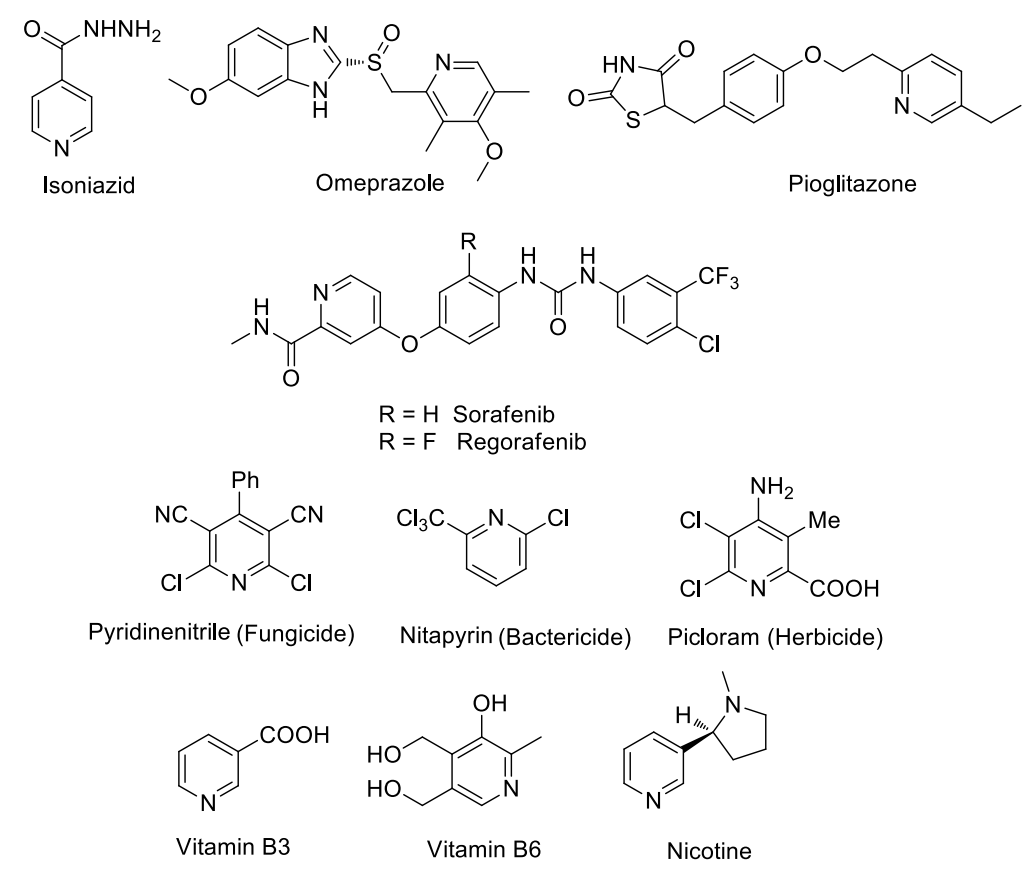

Figure 1. Structures of some pyridine containing pharmaceutical drugs, agrochemicals and a number of biologically active molecules.

Moreover, tetrahydronaphthalene derivatives have attracted much attention in the medicinal field because of their broad range of pharmacological properties. ${ }^{12-18}$ Furthermore, tetrahydronaphthalene (tetralin) is also an efficient ring, which is found in the structures of some anticancer drugs such as doxorubicin and epirubicin (Figure 2)..$^{19}$ 

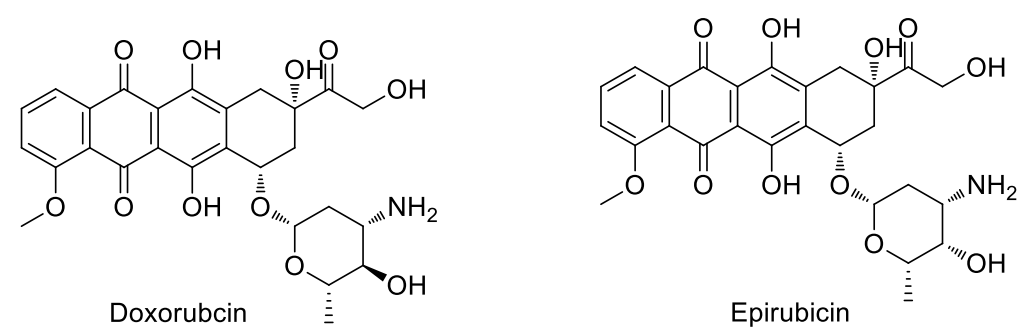

Figure 2. Tetralin containing anticancer drugs

Motivated by these findings and in conjunction with our ongoing research work on pyridine chemistry, ${ }^{20-25}$ as well as on the development of new anticancer agents with improved efficacy, high selectivity and minimum toxicities, ${ }^{26-28}$ we report herein the synthesis of novel derivatives based on 5,6,7,8-tetrahydronaphthalenepyridine scaffolds as new hybrid molecules. The anticancer activities of the new compounds have also been evaluated.

\section{Results and Discussion}

\section{Chemistry}

The starting 2-(pyridin-2-yl)oxy)acetohydrazide 7 was synthesized in a good yield using the synthetic route outlined in scheme 1 . Thus, according to our reported procedure, ${ }^{29}$ 2-oxo-6-(tetrahydronaphthalen-2-yl)-1,2dihydropyridine-3-carbonitrile 4 was obtained in a good yield by a four-component reaction of 2-acetyl5,6,7,8-tetrahydronaphthalene $\mathbf{1}^{30}$ with 4-fluorobenzaldehyde $\mathbf{2 a}$, ethyl cyanoacetate $\mathbf{3}$ and excess ammonium acetate in $n$-butanol at reflux. Reaction of 4 with ethyl bromoacetate 5 in the presence of anhydrous $\mathrm{K}_{2} \mathrm{CO}_{3}$ in dry acetone afforded ethyl 2-((3-cyano-4-(4-fluorophenyl)-6-(5,6,7,8-tetrahydronaphthalen-2-yl)pyridin-2yl)oxy)acetate 6, which upon treatment with hydrazine hydrate in absolute ethanol afforded the desired acetohydrazide $7^{31}$ (Scheme 1).

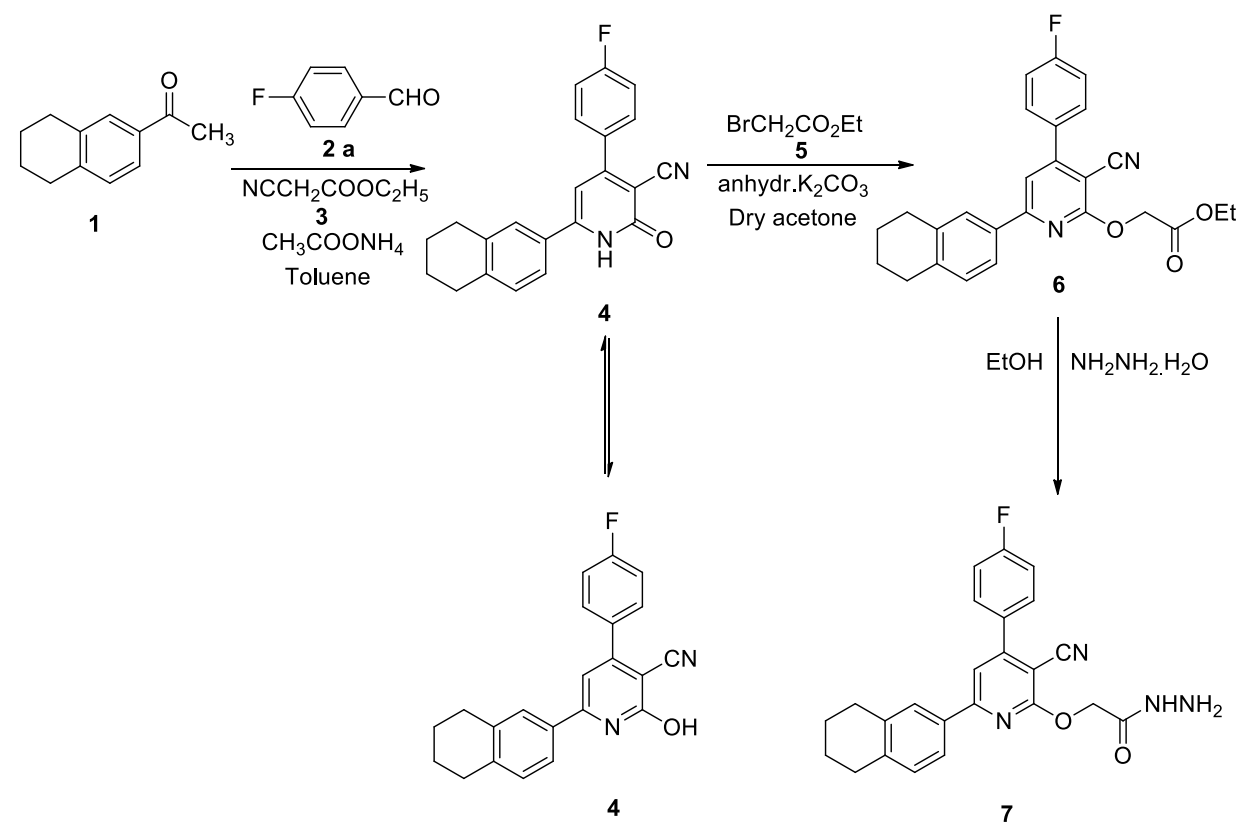

Scheme 1. Synthesis of the acetohydrazide compound 7. 
Hydrazides are useful important intermediates and their condensation products are reported to possess a wide range of biological activities. ${ }^{32,33}$ In this work, the acetohydrazide 7 was used as a versatile precursor for the synthesis of novel interesting pyridine derivatives, via its reactions with a variety of reagents (Scheme 2-6).

New Schiff base derivatives 8a-f were obtained by condensation of acetohydrazide derivative 7 with a series of aromatic aldehydes namely, 4-fluorobenzaldehyde $\mathbf{2 a}$, benzaldehyde $\mathbf{2 b}$, 4-bromobenzaldhyde $\mathbf{2 c}$, 4 chlorobenzaldehyde $\mathbf{2 d}$, 4-cyanobenzaldhyde $\mathbf{2 e}$ and 4-methoxybenzaldehyde $\mathbf{2} \mathbf{f}$ in ethanol and a catalytic amount of glacial acetic acid at reflux. The IR spectra of 8a-f revealed absorption bands between 3212-3198 and 2224-2220, 1681-1664 $\mathrm{cm}^{-1}$ assignable for $\mathrm{NH}, \mathrm{CN}$ and $\mathrm{C}=\mathrm{O}$ groups, respectively, while no absorption bands for the $\mathrm{NH}_{2}$ group in their spectra were detected. The disappearance of the absorption bands due to $\mathrm{NH}_{2}$ in both IR as well as in the ${ }^{1} \mathrm{H}$ NMR spectra of 8 confirmed that the hydrazide- $\mathrm{NH}_{2}$ completely reacted with - $\mathrm{CHO}$ groups of the used aldehydes leading to the formation of the corresponding Schiff bases (scheme 2). The ${ }^{1} \mathrm{H}$ and ${ }^{13} \mathrm{C}$ NMR spectra of the hydrazone derivatives $8 \mathrm{a}-\mathrm{f}$ displayed additional signals at the aromatic region due to aromatic ring protons derived from the aldehyde moiety, in addition to the characteristic signals belonging to benzylidene amino group $(\mathrm{CH}=\mathrm{N})$. The ${ }^{1} \mathrm{H}$ NMR spectra of compounds 8a-f exhibited two sets of signals each belonging to the $-\mathrm{OCH}_{2},-\mathrm{N}=\mathrm{CH}$ and $-\mathrm{NH}$ groups, of the trans and cis conformers, recorded between $\delta$ 5.61-5.64 and 5.07-5.12; 8.07-8.16 and 8.26-8.39; 11.64-12.01 and 11.80-12.19 ppm, respectively. In addition, the $\mathrm{C}_{4}$-proton of tetrahydronaphthalene appeared also as two doublets between 7.01-7.06 and 7.06-7.11 ppm, corresponding to trans and cis conformers. The ratios of trans/cis conformers in each case were calculated by using ${ }^{1} \mathrm{H}$ NMR data. The ${ }^{13} \mathrm{C}$ NMR spectra of these compounds revealed also two sets of signals between 62.77-66.28 and 63.47-66.93 ppm; 139.97-142.98 and 141.99-145.92 ppm characteristic for the $\mathrm{OCH}_{2}$ and $\mathrm{N}=\mathrm{CH}$ carbons, respectively. The $\mathrm{C}_{4}$ of tetrahydronaphthalene was also observed as two sets of signals between $\delta$ 127.42-128.86 and 127.58-129.35 ppm. Moreover, the $-\mathrm{OCH}_{3}$ protons of compound 8 f appeared as a singlet signal at $\delta 3.81 \mathrm{ppm}$ in the ${ }^{1} \mathrm{HNMR}$ spectrum, and its ${ }^{13} \mathrm{C}$ NMR spectrum revealed the $\mathrm{OCH}_{3}$ carbon at $\delta 56.07 \mathrm{ppm}$.

According to the literature, ${ }^{34-39}$ compounds having arylidene-hyrazide structure may exist as $E / Z$ geometrical isomers around $\mathrm{C}=\mathrm{N}$ double bonds and cis/trans amide conformers (Scheme 3 ). It has been reported that, compounds containing imine bond exists at higher percentage of the geometrical $E$ isomer about $-\mathrm{C}=\mathrm{N}$ double bond in dimethyl- $d_{6}$ sulfoxide solution. ${ }^{37}$ While the $Z$ isomer can be stabilized by an intramolecular hydrogen bond in less polar solvents. In compounds $\mathbf{8 a - f}$, no signal belonging to $Z$ isomer was observed as the ${ }^{1} \mathrm{H}$ NMR data were obtained in dimethyl- $d_{6}$ sulfoxide solution. On the other hand, the dimethyl- $d_{6}$ sulfoxide solution of compounds $\mathbf{8 a - f}$ indicated that among the cis/trans conformers of the geometrical $E$ isomer, the trans conformer predominates. ${ }^{34-37}$ 


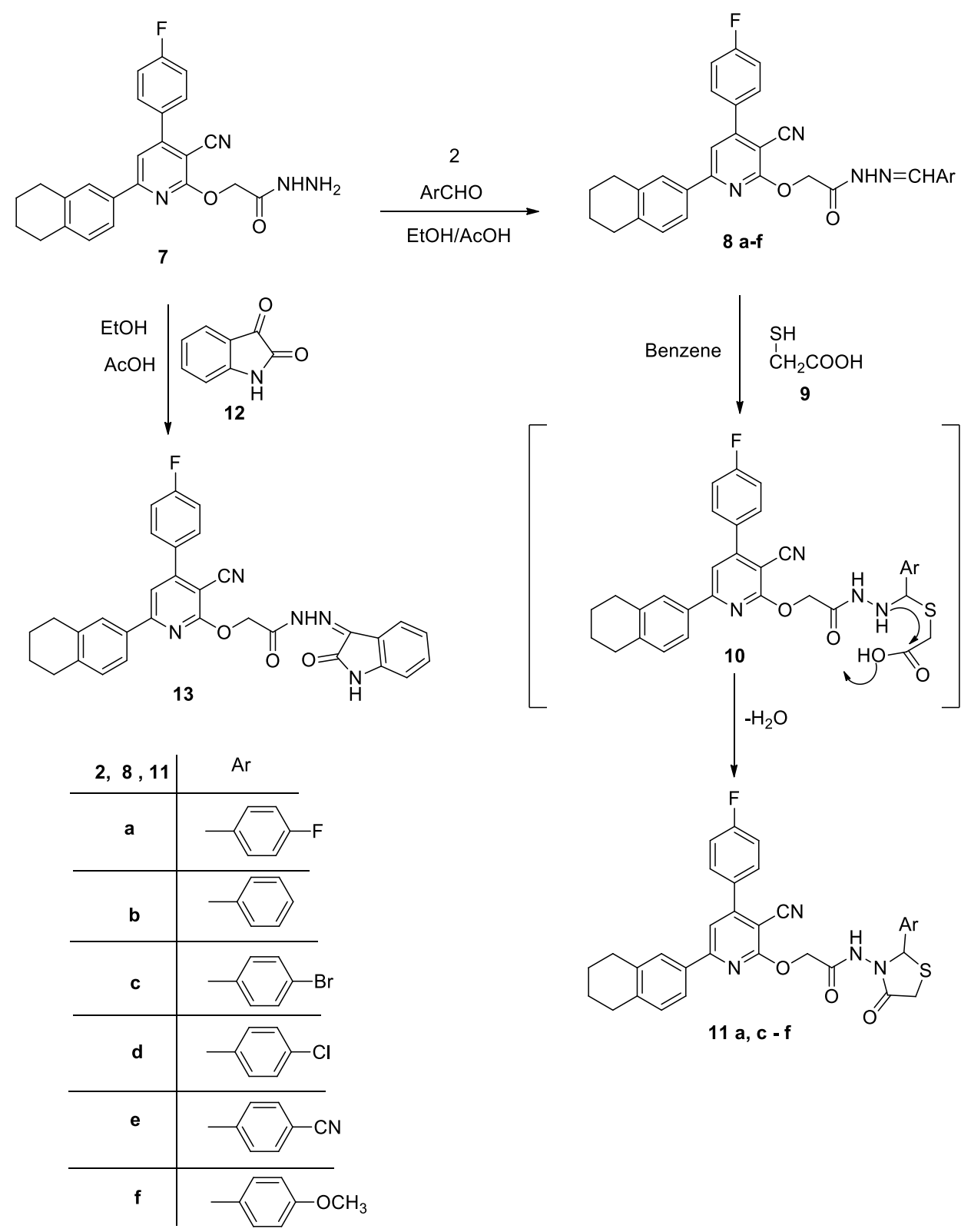

Scheme 2. Synthesis of compounds 8, 11 and 13.

The cis/trans conformer ratios of the $E$ isomers can easily be determined by ${ }^{1} \mathrm{H}$ NMR integration. The data obtained from chemical shift values of $\mathrm{OCH}_{2}, \mathrm{~N}=\mathrm{CH}$, and $\mathrm{NH}$ protons of cis/trans conformers in the ${ }^{1} \mathrm{H} N M R$ and that obtained from chemical shift values of $\mathrm{OCH}_{2}$ and $\mathrm{N}=\mathrm{CH}$ carbons in the ${ }^{13} \mathrm{C} N \mathrm{NM}$ spectra of compounds 8 proved that the $E$ isomers and trans conformer structures (I) are the dominant forms among the four possible structures. ${ }^{34-37}$ In the the trans conformers, the proton signals of $\mathrm{N}=\mathrm{CH}$ and $\mathrm{NH}$, are shifted upfield compared to those of the cis conformer. On the other hand, because of the steric hindrance, the $\mathrm{OCH}_{2} \mathrm{proton}$ signal of the trans conformer is shifted downfield compared to the that of the cis conformer. ${ }^{34}$ 

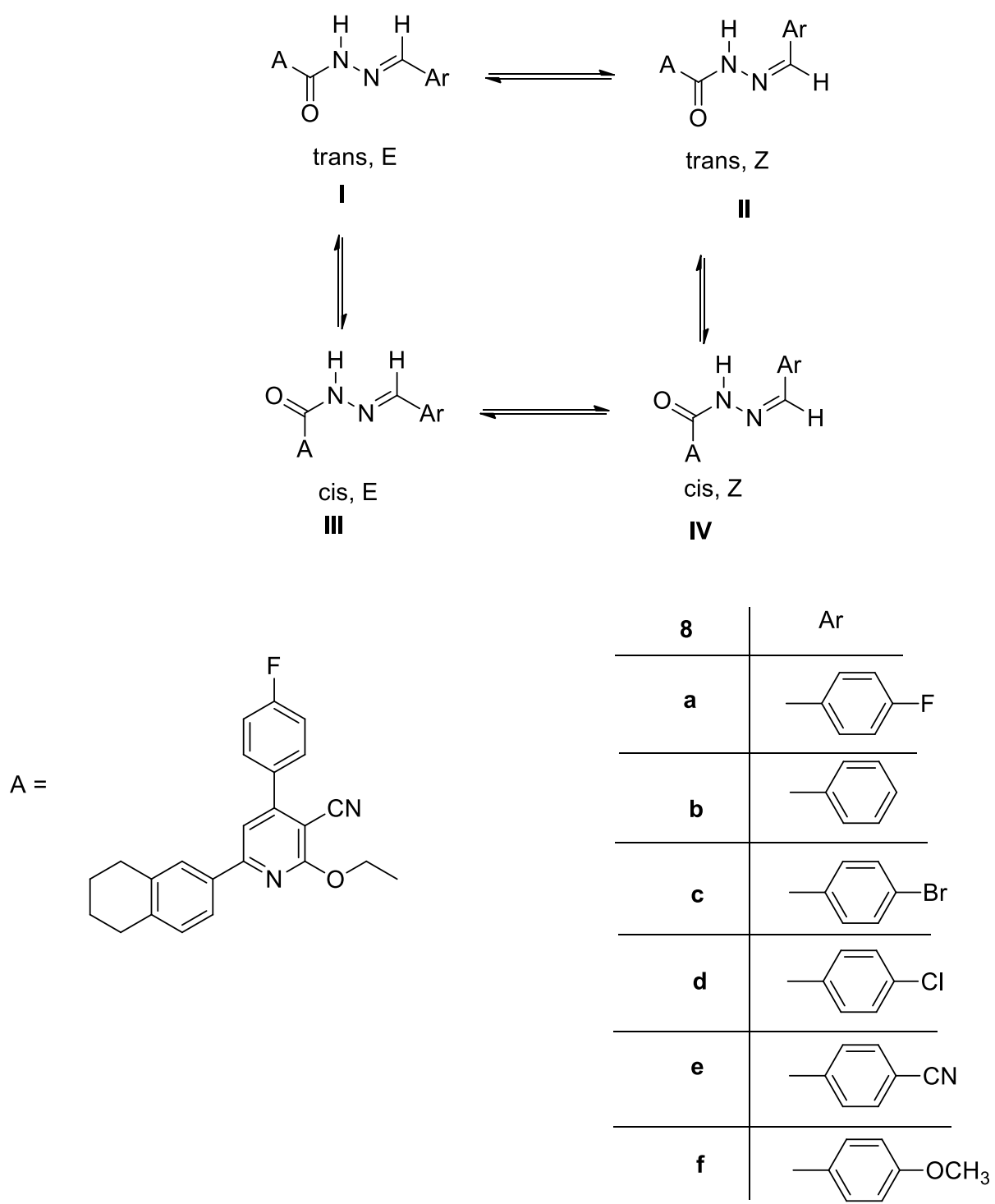

Scheme 3. E/Z Geometrical isomers and cis/trans amide conformers of compounds 8a-f.

Compounds 8a-f containing imine bond have been synthesized for preparing other derivatives like thiazolidinones due to their broad spectrum of biological activities. ${ }^{40}$ Thiazolidinone derivatives belong to the most frequently studied moieties of medicinal interest which attributed to the presence of thiazolidine in the structre of penicillin. ${ }^{41}$

The 4-thiazolidinone derivatives $\mathbf{1 1 a}$ and $\mathbf{1 1 c - f}$ were synthesized by refluxing the imine $\mathbf{8 a}$ and $\mathbf{8 c - f}$ with thioglycolic acid 9 in dry benzene according to the reported method (Scheme 2). ${ }^{42}$ The formation of thiazolidinone derivatives were assumed to occur by the addition of the SH group of thioglycolic acid to the $\mathrm{CH}=\mathrm{N}$ bond of the hydrazine moiety of $8 \mathrm{a}$ and $8 \mathrm{c}-\mathrm{f}$ to yield the corresponding acyclic non-isolable intermediates $\mathbf{1 0}$ which underwent the elimination of water molecule by intramolecular cyclization to afford the final cyclocondensation products $11 .^{43}$

The structures of the newly synthesized compounds were confirmed by IR, ${ }^{1} \mathrm{H}-\mathrm{NMR}$ and ${ }^{13} \mathrm{C}-\mathrm{NMR}$ as well as elemental analyses. The IR spectra of compounds 11a and 11c-d showed absorption bands at 3435-3441 (NH), 2220-2224 (CN), 1711-1729 (C=O of 4-thiazolidinone ring) and 1675-1685 cm ${ }^{-1}$ (C=O amide). The ${ }^{1} \mathrm{H}-$ NMR spectra for 11a and 11c-f showed the two methylene protons of the thiazolidinone ring as doublet of doublets signals at $\delta 3.73-3.77,3.85-3.93 \mathrm{ppm}$ and the methine protons as singlet signals at $\delta 5.68-5.83 \mathrm{ppm}$. 
The $\mathrm{OC}_{2}$ groups appeared as doublet of doublets signals between $\delta 5.00-5.06,5.09-5.15 \mathrm{ppm}$ and the $\mathrm{NH}$ groups appeared as singlet signals at $\delta 10.57-10.82 \mathrm{ppm} .{ }^{13} \mathrm{C}$ NMR spectral data also supports the formation of compounds 11a and 11c-f. Thus, the two carbonyl groups were observed between $\delta 166.55-167.11$ and 168.21-168.87 ppm; the $\underline{\mathrm{S}}_{2} \mathrm{CO}$ and the $\mathrm{N} \underline{\mathrm{C}} \mathrm{HS}$ carbons appeared at $\delta 32.71-35.39 \mathrm{ppm}$ and at $\delta$ 59.65-65.38 ppm, respectively.

Moreover, condensation of $\mathbf{7}$ with isatin $\mathbf{1 2}$ in ethanol at reflux in the presence of a catalytic amount of glacial acetic acid yielded the hydrazone derivative 13. The structure of $\mathbf{1 3}$ was confirmed by IR spectrum which showed absorption bands at 3427 and $3212 \mathrm{~cm}^{-1}$ due to $(2 \mathrm{NH})$ and at 2228, 1709 and $1657 \mathrm{~cm}^{-1} \mathrm{due}$ to $\mathrm{CN}, \mathrm{C}=\mathrm{O}$ of isatin ring and $\mathrm{C}=\mathrm{O}$ (amide), respectively. Moreover, the ${ }^{1} \mathrm{H}$ NMR spectrum of 13 showed a $\mathrm{D}_{2} \mathrm{O}-$ exchangeable $\mathrm{NH}$ signal at $\delta 11.35 \mathrm{ppm}$ characteristic for the $\mathrm{NH}$ proton of the isatin moiety. On the other hand, the hydrazine function proton ( $=\mathrm{N}-\mathrm{NH}-)$ appeared as two singlet signals at $\delta 12.78$ and $13.40 \mathrm{ppm}$, respectively, due to trans/cis conformers. Furthermore, the ${ }^{13} \mathrm{C}$ NMR spectrum of this compound showed two carbonyl groups at $\delta 167.90$ and 168.75 ppm, confirming the structure of 13 (Scheme 2).

Fusion of a mixture of acetic acid hydrazide $\mathbf{7}$ and acetic anhydride $\mathbf{1 4}$ afforded the new acetic- $N$ '-acetyl-2((3-cyano-4-(4-fluorophenyl)-6-(5,6,7,8-tetrahydronaphthalen-2-yl)pyridin-2-yl)oxy)acetohydrazonic anhydride 15 (Scheme 4). The IR spectrum of 15 revealed the presence of two bands at 1742 and $1670 \mathrm{~cm}^{-1}$ due to the acetoxy $\mathrm{C}=\mathrm{O}$ and the amide $\mathrm{C}=\mathrm{O}$, respectively, which is in agreement with that reported in the literature. ${ }^{44}$ In addition, the ${ }^{1} \mathrm{H}$ NMR spectrum of 15 showed two methyl protons at $\delta 2.34 \mathrm{ppm}$ and at $\delta 2.35 \mathrm{ppm}$ for NHCO$\underline{\mathrm{CH}}_{3}$ and for $\mathrm{OCO}-\underline{\mathrm{CH}}_{3}$, respectively. Likewise, the ${ }^{13} \mathrm{C}$ NMR spectrum of 15 showed the two methyl carbons of the acetoxy and the acetamide groups at $\delta 22.49$ and 22.58 ppm, respectively, in addition to the two carbonyl groups at $\delta 168.63$ and 170.56 ppm, respectively.

Benzoylation of 7 was achieved via its reaction with benzoyl chloride 16 in refluxing pyridine to give $N^{\prime}-(2-$ ((3-cyano-4-(4-fluorophenyl)-6-(5,6,7,8-tetrahydronaphthalen-2-yl)pyridin-2-yl)oxy)acetyl)benzohydrazide 17 (Scheme 4).

The IR spectrum of compound 17 revealed strong absorption bands at $u$ 3432, 3230, 1728 and $1716 \mathrm{~cm}^{-1}$ attributable to two $\mathrm{NH}$ groups and two $\mathrm{C}=\mathrm{O}$ groups, respectively. The ${ }^{1} \mathrm{H}$ NMR spectrum of compound 17 revealed two singlets at $\delta 10.37$ and $\delta 10.46 \mathrm{ppm}$ assigned to the two $\mathrm{NH}$ protons, in addition to multiplet signals in the region $\delta 7.45-7.99 \mathrm{ppm}$ characteristic to the aromatic protons. ${ }^{13} \mathrm{C}$ NMR spectrum of 17 gave a further evidence for its structure as it showed the two carbonyl groups at $\delta 165.36$ and 168.08 ppm, respectively.

Our study was extended to include the synthesis of 2-((3-cyano-4-(4-fluorophenyl)-6-(5,6,7,8tetrahydronaphthalen-2-yl)pyridin-2-yl)oxy)- $N$ '-formylacetohydrazide $\mathbf{1 9}$ in good yields by heating acetohydrazide 7 with formic acid 18 at reflux (Scheme 4). The IR spectrum of compound 19 displayed an absorption band at $1724 \mathrm{~cm}^{-1}$ corresponding to the carbonyl $\mathrm{C}=\mathrm{O}$ of the formyl group, which appeared in the ${ }^{13} \mathrm{C}$ NMR spectrum at $\delta 169.7 \mathrm{ppm}$. Its ${ }^{1} \mathrm{H}$ NMR spectrum revealed a singlet at $\delta 8.04 \mathrm{ppm}$ assigned to the formyl proton. 


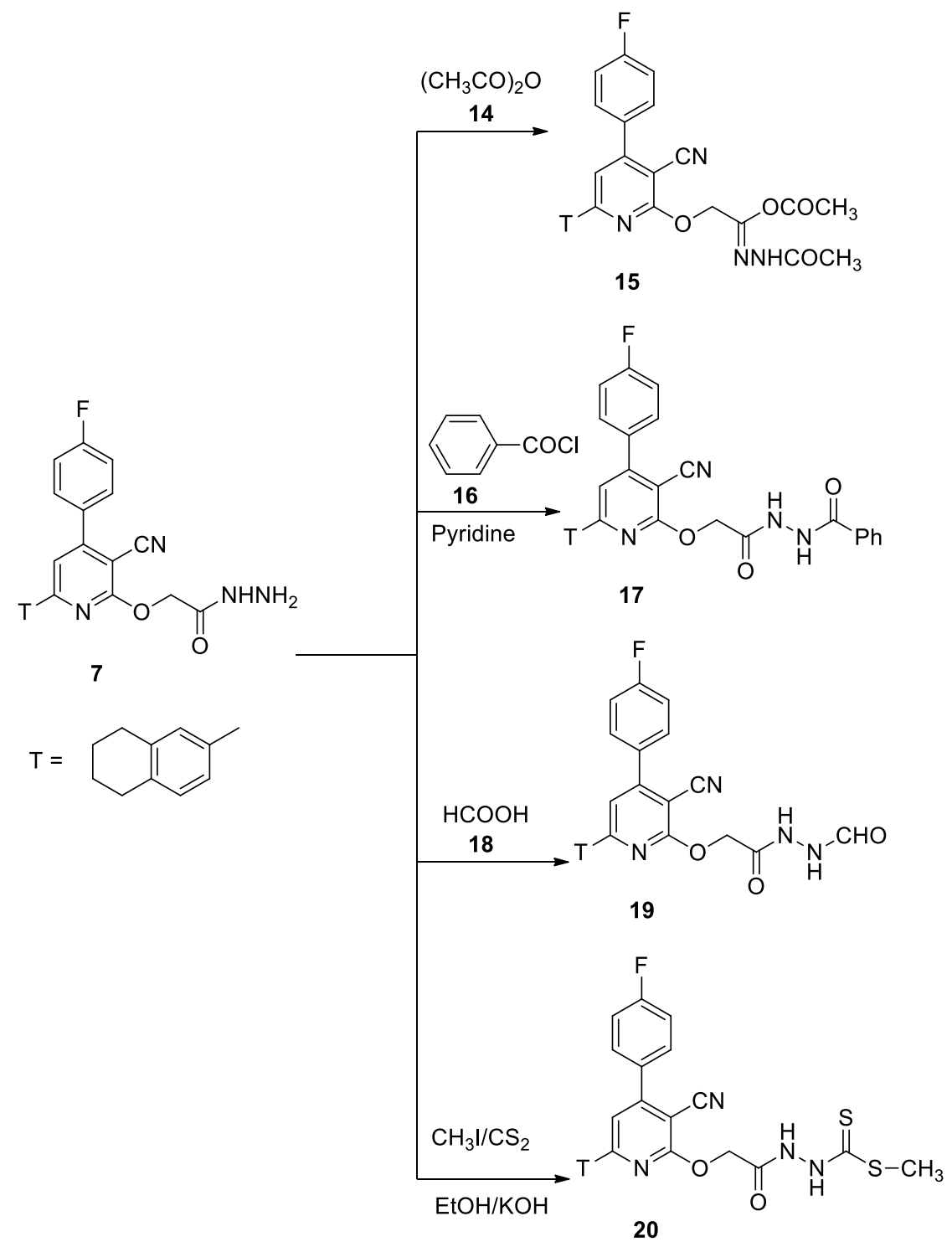

Scheme 4. Synthesis of compounds 15, 17, 19 and 20.

Methyl (pyridin-2-yl)oxy)acetyl)hydrazine-1-carbodithioate $\mathbf{2 0}$ was also synthesized by the reaction of acetohydrazide $\mathbf{7}$ with carbon disulfide and methyl iodide in ethanolic solution in the presence of triethylamine (TEA), according to the reported method. ${ }^{45}$ The structure of this compound was confirmed according to its correct analytical and spectroscopic data. The ${ }^{1} \mathrm{HNMR}$ spectrum of 20 showed signals at $\delta$ 10.76 and at $\delta 10.80$ assigned for two $\mathrm{NH}$ protons and at $2.56 \mathrm{ppm}$ corresponding to $-\mathrm{SC}_{\underline{3}}$ group while its carbon appeared at $\delta 19.56 \mathrm{ppm}$ in the ${ }^{13} \mathrm{C}$ NMR in addition to the $\mathrm{C}=\mathrm{S}$ which appeared at $\delta 205.10 \mathrm{ppm}$. Further structural verification was obtained from its mass spectroscopy, which showed the correct molecular ion peak at $\mathrm{m} / \mathrm{z} 506.30\left(\mathrm{M}^{+}, 100\right)$.

The acetohydrazide derivative $\mathbf{7}$ is also a very useful intermediate for further cyclocondensation reactions. Thus, cyclocondensation of $\mathbf{7}$ with acetylacetone $\mathbf{2 1}$ afforded the corresponding dimethylpyrazole derivative 23 as a single product via initial formation of the intermediate hydrazone $\mathbf{2 2}^{43}$ (Scheme 5). The structure of compound 23 was confirmed based on the IR, ${ }^{1} \mathrm{H} N \mathrm{NMR},{ }^{13} \mathrm{C}$ NMR and mass spectral data, which were in agreement with the assigned structure. Thus, the absence of signals corresponding to $\mathrm{NH}, \mathrm{NH}_{2}$ protons in both the IR and ${ }^{1} \mathrm{H}$ NMR spectra confirmed that they were involved in the cyclization. Also, ${ }^{1} \mathrm{H}-\mathrm{NMR}$ spectrum of 23 showed two singlets at $\delta 2.29 \mathrm{ppm}$ and $2.45 \mathrm{ppm}$ characteristic for the two $\underline{\mathrm{C}}_{3}$ groups and a singlet at $\delta 6.35$ 
ppm due to the $\mathrm{H}-4$ of the pyrazole moiety. The ${ }^{13} \mathrm{C}$ NMR spectral of 23 revealed two characteristic singlets at $\delta 150.45$ and $154.54 \mathrm{ppm}$ for C3 and C5 of the pyrazole nucleus, respectively, in addition to the two methyl groups at $\delta 13.56$ and $13.60 \mathrm{ppm}$.

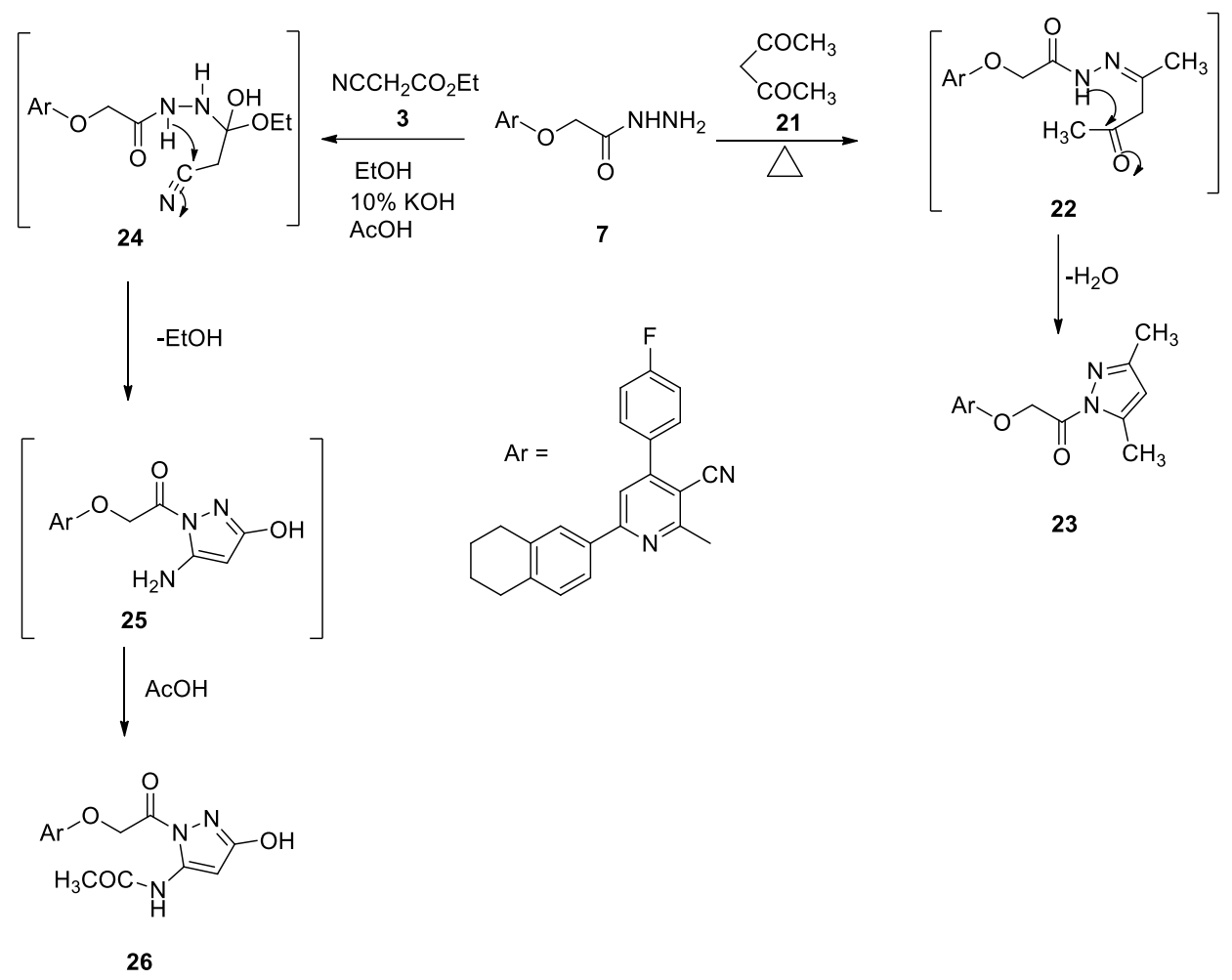

Scheme 5. Synthesis of compounds 23 and 26.

Furthermore, cyclocondensation of $\mathbf{7}$ with ethyl cyanoacetate in ethanol containing $\mathrm{KOH}$ at reflux gave a novel pyrazole derivative 26. The formation of this compound proceeded through nucleophilic transformation to give the non-isolable acyclic intermediate $\mathbf{2 4}$, followed by intramolecular cyclization via loss of ethanol molecule and tautomerization under the reaction conditions to give 25. Subsequent acetylation of the amino group of $\mathbf{2 5}$ afforded the final product $\mathbf{2 6}$ in a good yield (Scheme 5). The structure of $\mathbf{2 6}$ was confirmed based on its correct analytical and spectral data. Its IR spectrum showed absorption bands at $u 3440(\mathrm{OH}), 3196(\mathrm{NH})$, $2218(\mathrm{CN})$ and $1606(\mathrm{C}=\mathrm{O}) \mathrm{cm}^{-1}$. Also, the ${ }^{1} \mathrm{H}-\mathrm{NMR}$ spectrum of compound 26 indicated the presence of a singlet signal integrated by three protons at $\delta 1.87 \mathrm{ppm}$ for $\mathrm{COCH}_{3}$ protons, and a singlet signal integrated by two protons at $\delta 5.11 \mathrm{ppm}$ assigned to methylene protons. In addition, the aromatic protons as well as the pyrazole-H4 appeared at $\delta 7.42-7.93 \mathrm{ppm}$, in addition to signals at $\delta 9.89$ and $10.21 \mathrm{ppm}$ characteristic for $\mathrm{NH}$ and $\mathrm{OH}$ groups, respectively.

On the other hand, attempted synthesis of pyrazole $\mathbf{2 9}$ via the reaction of acetohydrazide $\mathbf{7}$ with [bis(methylthio)methylene] malononitrile $\mathbf{2 7}$ in ethanol was unsuccessful. The reaction gave instead the oxadiazole derivative 30. The reaction seems to proceed via initial formation of the expected acyclic intermediate 2-((3-cyano-4-(4-fluorophenyl)-6-(5,6,7,8-tetrahydronaphthalen-2-yl)pyridin-2-yl)oxy)-N'-(2,2dicyano-1-(methyl-thio)vinyl)acetohydrazide 28, which upon intramolecular nucleophilic cyclization by elimination of methylthiol molecule afforded the oxadiazol derivative $\mathbf{3 0}$ (Scheme 6).

The absence of sulfur element in the product of this reaction together with the disappearance of the amino $\mathrm{NH}_{2}$ group in both IR and ${ }^{1} \mathrm{H}-\mathrm{NMR}$ as well as the disappearance of $\mathrm{C}=\mathrm{O}$ in both the IR and ${ }^{13} \mathrm{C}$-NMR spectra 
confirmed the exclusion of 29. Moreover, ${ }^{1} \mathrm{H}-\mathrm{NMR}$ and ${ }^{13} \mathrm{C}-\mathrm{NMR}$ spectra revealed the loss of the methylthio groups that can be considered as a strong evidence for the formation of the oxadiazol derivative $\mathbf{3 0}$ which in agreement with that related in the literature. ${ }^{43}$

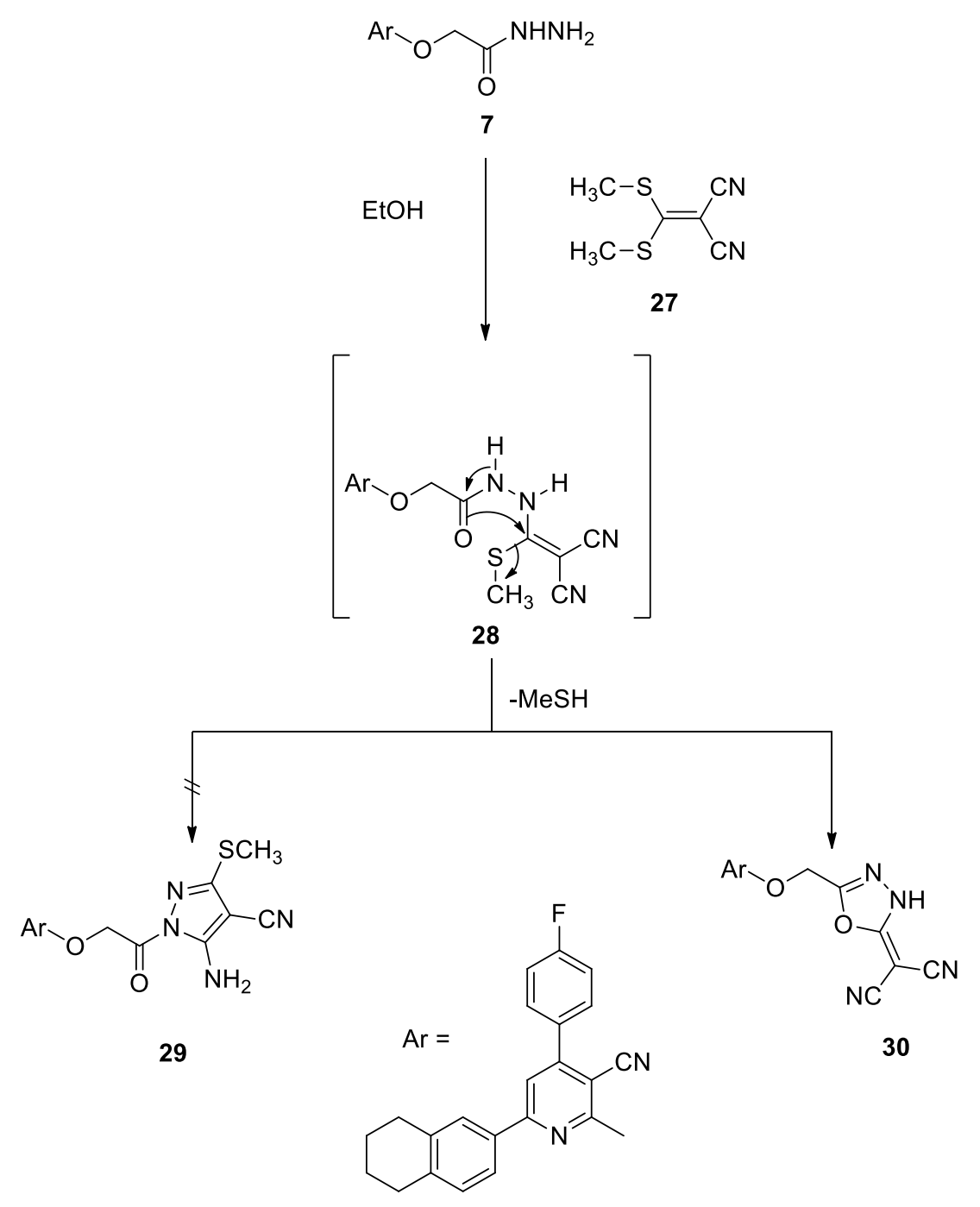

Scheme 6. Synthesis of compound $\mathbf{3 0}$ from acetohydrazide $\mathbf{7}$.

\section{In-vitro cytotoxicity activities}

The in vitro cytotoxic activity of twenty compounds of the synthesized compounds were evaluated against human colorectal carcinoma cell line (HCT116) and human breast cancer cell line (MCF-7) using MTT assay. The percentages of the viable cells was measured and compared to that obtained by the positive control Doxorubicin $^{\circledast}$ (Fig.3,4). The cytotoxic activities of the tested compounds were also expressed as $I C_{50} \mu M$ values (the dose that reduces survival to 50\%). Regarding the activity of the evaluated compounds against HCT116 cancer cells, the results in Table 1 showed that the compounds possessed high cytotoxicity approximately equal to that obtained by doxorubicin ( $\mathrm{IC}_{50}$; 7.7-9.0 $\mu \mathrm{M}, \mathrm{IC}_{50}$ doxorubicin; $\left.8.0 \mu \mathrm{M}\right)$. Concerning MCF-7 cancer cells, it is evident that there is a wide variation in the cytotoxic potency of the tested compounds. Interestingly, the $N^{\prime}$-formylacetohydrazide derivative $\mathbf{1 9}$ was approximately three times more active than DOX $\left(\mathrm{IC}_{50} ; 21.0 \mu \mathrm{M}, \mathrm{IC}_{50}\right.$ doxorubicin; $\left.68.4 \mu \mathrm{M}\right)$. On the other hand, the activity decreased slightly by the acetohydrazonic anhydride derivative 15 to be twice that of the reference drug (IC $50 ; 33.3 \mu \mathrm{M})$. Although linking the thiazolidinone ring to the oxyacetamide side chain as compound 11c led to a decrease in the 
potency, but it is still a promising antitumor agent comparable to DOX (IC $50 ; 60.3 \mu \mathrm{M})$. It could be noted that the starting acetohydrazide compound 7 and its $p$-fluorophenyl shiff's base analogue 8 a appeared to be slightly less potent cytotoxic candidates than DOX of $\mathrm{IC}_{50}$ values; 72.7 and $71.0 \mu \mathrm{M}$, respectively. The results also showed that the rest of the tested derivatives were weaker than DOX of $\mathrm{IC}_{50}$ values ranging from 78.0$110.9 \mu \mathrm{M}$. It could be concluded that tetralin-pyridine backbone is an interesting antitumor pharmacophore against the breast cancer cells (MCF-7). The above mentioned data reveal that all the evaluated compounds are more active against the human colon cancer type rather than against the human breast cancer type. Further structural modifications and optimization are needed to signify and widen the antitumor spectrum of the derivatives bearing tetralin-pyridine motif.

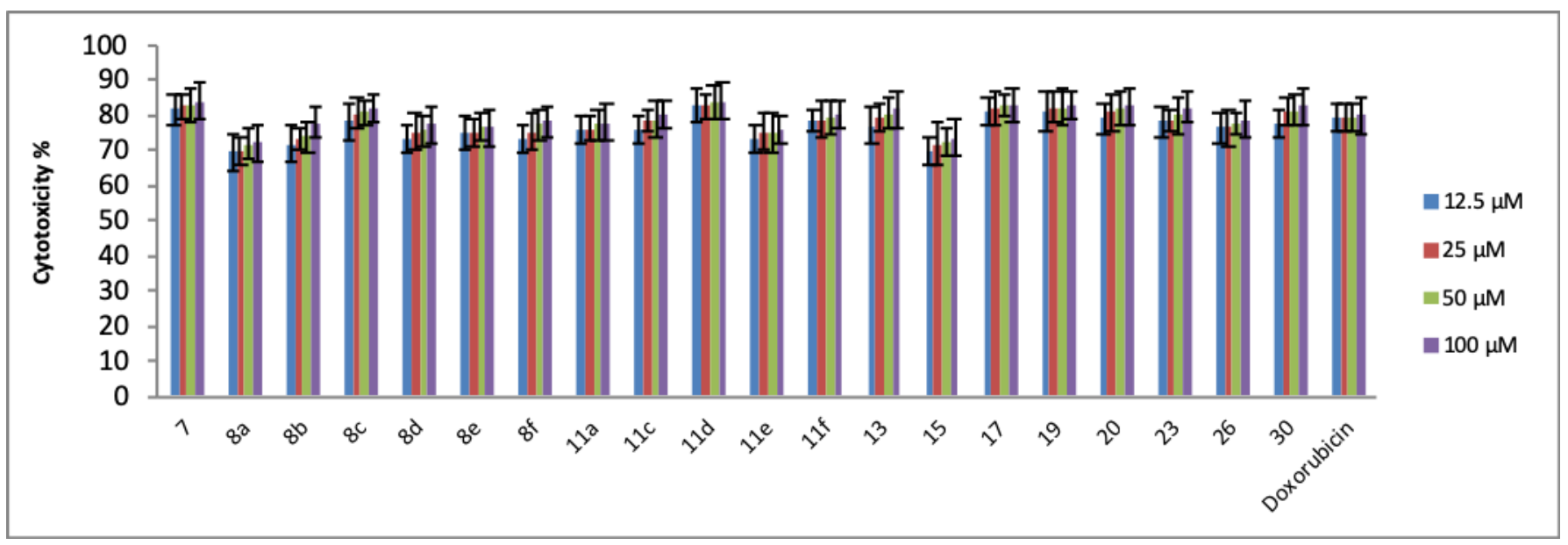

Figure 3. Dose dependent cytotoxicity percentages curve of the synthesized compounds on HCT-116 human cancer cells according to MTT assay.

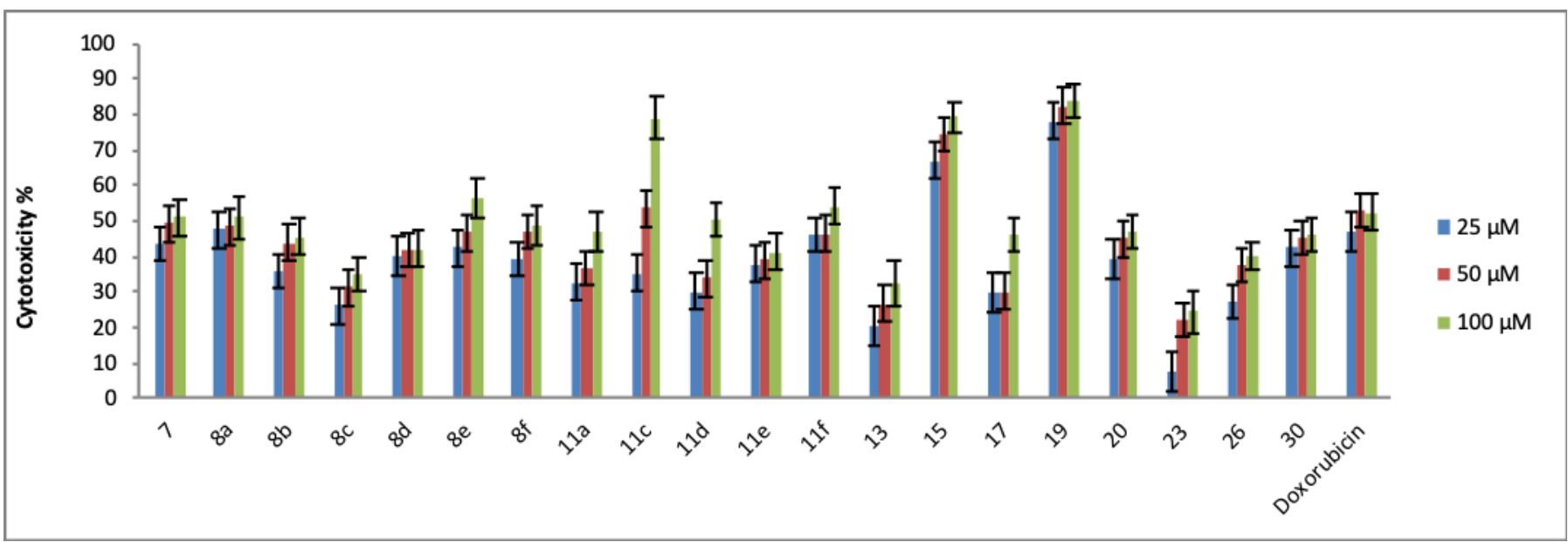

Figure 4. Dose dependent cytotoxicity percentages curve of the synthesized compounds on MCF-7 human cancer cells according to MTT assay.

Table 1. Anticancer IC $\mathrm{C}_{50}$ values of the tested compounds using MTT assay on the human colorectal and breast cancer cells 


\begin{tabular}{ccc}
\hline Compound & \multicolumn{2}{c}{ IC $_{50}(\mu \mathrm{M}) \pm$ SD } \\
\cline { 2 - 3 } & HCT-116 & MCF-7 \\
\hline $\mathbf{7}$ & $8.5 \pm 2.1$ & $72.7 \pm 5.8$ \\
$\mathbf{8 a}$ & $8.6 \pm 2.3$ & $71.0 \pm 5.1$ \\
$\mathbf{8 b}$ & $8.0 \pm 2.5$ & $82.3 \pm 6.5$ \\
$\mathbf{8 c}$ & $7.9 \pm 1.9$ & $102.3 \pm 7.1$ \\
$\mathbf{8 d}$ & $8.1 \pm 2.1$ & $83.0 \pm 6.1$ \\
$\mathbf{8 e}$ & $8.1 \pm 1.8$ & $71.9 \pm 4.1$ \\
$\mathbf{8 f}$ & $7.7 \pm 1.9$ & $77.3 \pm 3.7$ \\
$\mathbf{1 1 a}$ & $8.2 \pm 2.1$ & $87.9 \pm 5.9$ \\
$\mathbf{1 1 c}$ & $9.0 \pm 2.4$ & $60.3 \pm 5.1$ \\
$\mathbf{1 1 d}$ & $8.6 \pm 2.3$ & $88.8 \pm 5.8$ \\
$\mathbf{1 1 e}$ & $8.3 \pm 2.5$ & $86.3 \pm 4.7$ \\
$\mathbf{1 1 f}$ & $8.7 \pm 2.8$ & $71.0 \pm 4.1$ \\
$\mathbf{1 3}$ & $7.7 \pm 1.6$ & $110.9 \pm 5.9$ \\
$\mathbf{1 5}$ & $7.6 \pm 1.5$ & $33.3 \pm 2.1$ \\
$\mathbf{1 7}$ & $8.0 \pm 1.9$ & $94.0 \pm 4.5$ \\
$\mathbf{1 9}$ & $8.0 \pm 2.1$ & $21.0 \pm 2.1$ \\
$\mathbf{2 0}$ & $8.2 \pm 2.3$ & $79.4 \pm 4.1$ \\
$\mathbf{2 3}$ & $7.7 \pm 1.9$ & $131.5 \pm 5.1$ \\
$\mathbf{2 6}$ & $9.0 \pm 2.3$ & $94.5 \pm 4.5$ \\
$\mathbf{3 0}$ & $8.4 \pm 2.1$ & $78.0 \pm 4.1$ \\
Doxorubicin & $8.0 \pm 2.1$ & $68.4 \pm 4.1$ \\
\hline
\end{tabular}

\section{Conclusions}

We successfully synthesized a new series of tetralin-pyridine hybrids in good yields by reacting 2-((3-cyano-4(4-fluorophenyl)-6-(5,6,7,8-tetrahydronaphthalen-2-yl)pyridin-2-yl)oxy)acetohydrazide with a variety of reagents. The structures of the new compounds were confirmed by spectral data as well as elemental analyses. Study of the cytotoxic activity of the new compounds on HCT116 and MCF-7 human cancer cells using MTT assay revealed that these compounds are potent cytotoxic on the human colon cancer type and some of them showed good activities against breast cancer in vitro.

\section{Experimental Section}

\section{Chemistry}

General. All melting points are uncorrected and were taken in open capillary tubes using an Electro-thermal IA 9100 apparatus (Shimadzu, Japan). Microanalytical data were performed by Vario El-Mentar apparatus (Shimadzu, Japan), National Research Centre (NRC), Cairo, Egypt. The found values were within $\pm 0.4 \%$ of the theoretical values. Infrared spectra $(\mathrm{KBr})$ were recorded on a Perkin-Elmer 1650 spectrophotometer, NRC. ${ }^{1} \mathrm{H}$ NMR and ${ }^{13} \mathrm{C}$ NMR spectra were determined on a Varian Mercury (run at $300 \mathrm{MHz}$ for ${ }^{1} \mathrm{H} \mathrm{NMR}$ and $75 \mathrm{MHz}$ for ${ }^{13} \mathrm{C}$ NMR) spectrometer (Varian, UK) (Faculty of Science, Cairo University, Egypt) or with a Bruker AVANCE 400 
$\mathrm{MHz}$ spectrometer (Bruker) (Aalto university school of chemical engineering, Finland) with a $5 \mathrm{~mm}$ BBFO probe using deuterated dimethylsulfoxide DMSO as a solvent and the chemical shifts were expressed in $\delta \mathrm{ppm}$ relative to TMS as an internal reference. Mass spectra were recorded at $70 \mathrm{eV}$ on EI Ms-QP 1000 EX (Shimadzu, Japan), NRC. Follow-up of the reactions and checking of the purity of the compounds were made by TLC on silica gel precoated aluminum sheets (Type 60, F 254, Merck, Darmstadt, Germany) and the spots were detected by exposure to a UV lamp at $254 \mathrm{~nm}$ for a few seconds. The chemical names for the prepared compounds are given according to the IUPAC system. Compounds $\mathbf{1}^{29}, \mathbf{4 ,} 6$ and $\mathbf{7}$ were prepared as reported in the literature. ${ }^{30,31}$

\section{General procedure for synthesis of compounds (8a-f)}

A mixture of acetohydrazide (7) $(0.4165 \mathrm{~g}, 1 \mathrm{mmol})$ and the appropriate aromatic aldehyde namely: 4fluorobenzaldehyde (2a), benzaldehyde (2b), 4-bromobenzaldhyde (2c), 4-chlorobenzaldehyde (2d), 4cyanobenzaldhyde (2e) and 4-methoxybenzaldehyde (2f) $(1 \mathrm{mmol})$ in absolute ethanol (30 ml), was treated with acetic acid $(0.5 \mathrm{~mL})$. The clear solution was then heated at reflux for $6 \mathrm{~h}$. The solid precipitate so formed during the course of the reaction on heating was collected by filtration, washed by hot ethanol and crystallized from acetic acid to give the benzylidene derivatives 8 a-f.

\section{(2-((3-Cyano-4-(4-fluorophenyl)-6-(5,6,7,8-tetrahydronaphthalen-2-yl)pyridin-2-yl)oxy)-N'-(4-fluoro-}

benzylidene)acetohydrazide (8a). Yield 64\%; colorless crystals; m.p. $248-249{ }^{\circ} \mathrm{C}$, the ratio of trans/cis conformers: 76/24; IR spectrum ( $\left.\mathrm{KBr}, \mathrm{cm}^{-1}\right)$ : $3198(\mathrm{NH}), 2925(\mathrm{CH}$, alicyclic), $2221(\mathrm{CN}), 1674$ (hydrazide $\mathrm{C}=0)$, $1600(\mathrm{C}=\mathrm{N}), 1236$ (C-F); ${ }^{1} \mathrm{HNMR}\left(400 \mathrm{MHz}, \mathrm{DMSO}-\mathrm{d}_{6}, \delta \mathrm{ppm}\right): 1.67$ (br.s, $4 \mathrm{H}, 2 \mathrm{CH}_{2}$ of tetrahydronaphthalene), $2.69\left(\mathrm{~m}, 4 \mathrm{H}, 2 \mathrm{CH}_{2}\right.$ of tetrahydronaphthalene), 5.62, $5.09\left(2 \mathrm{~s}, 2 \mathrm{H}, \mathrm{OCH}_{2}\right.$ trans/cis conformers), $7.06,7.11(2 \mathrm{~d}, \mathrm{~J}$ $8.0 \mathrm{~Hz}, 8.0 \mathrm{~Hz} 1 \mathrm{H}, \mathrm{C}_{4}$-proton of tetrahydronaphthalene, trans/cis conformers), 7.44-7.55 (m, 4H, Ar- $\left.\mathrm{H}\right), 7.73-$ $7.86(\mathrm{~m}, 7 \mathrm{H}, \mathrm{Ar}-\mathrm{H}), 8.11,8.33(2 \mathrm{~s}, 1 \mathrm{H}, \mathrm{N}=\mathrm{CH}$ trans/cis conformers), 11.84, $12.03(2 \mathrm{~s}, 1 \mathrm{H}, \mathrm{NH}$ exchangeable with $\mathrm{D}_{2} \mathrm{O}$ trans/cis conformers); ${ }^{13} \mathrm{C}$ NMR $(101 \mathrm{MHz}, \mathrm{DMSO}) \delta: 22.40\left(2 \mathrm{CH}_{2}\right), 28.64,28.77\left(2 \mathrm{CH}_{2}\right), 66.28,66.93\left(\mathrm{OCH}_{2}\right.$ trans/cis conformers), 115.77 (CN), 127.94, 128.17 (C-4 of tetrahydronaphthalene, trans/cis conformers), $142.84,144.48$ ( $\mathrm{N}=\underline{\mathrm{C}} \mathrm{H}$ trans/cis conformers), (91.43, 106.06, 115.77, 115.99, 124.43, 129.35, 131.07, 131.16, $132.17,133.46,137.08,139.98,155.24,157.08,162.56,162.25)(22$, Ar-C), 168.68 (hydrazide C=O); MS, $\mathrm{m} / \mathrm{z}$ (\%): $522.25\left(\mathrm{M}^{+}, 7\right), 520.37\left(\mathrm{M}^{+}-2,2\right), 358.13(41), 357.16$ (100), $357.13(71), 345.12(44), 344.11(100), 343.11$ (31); Analysis calcd. for: $\mathrm{C}_{31} \mathrm{H}_{24} \mathrm{~F}_{2} \mathrm{~N}_{4} \mathrm{O}_{2}$ (522.56): C, 71.25; $\mathrm{H}, 4.63 ; \mathrm{F}, 7.27 ; \mathrm{N}, 10.72$; Found: C, 71.19; H, 4.58; F, 7.25; N, 10.79.

\section{N'-Benzylidene-2-((3-cyano-4-(4-fluorophenyl)-6-(5,6,7,8-tetrahydronaphthalen-2-yl)pyridin-2-yl)oxy)-}

acetohydrazide (8b). Yield 52\%; light beige crystals; m.p. $260-261^{\circ} \mathrm{C}$; the ratio of trans/cis conformers: $75 / 25$. IR ( $\left.\mathrm{KBr}, \mathrm{cm}^{-1}\right)$ : $3223(\mathrm{NH}), 2927$ (CH, alicyclic), 2220 (CN), 1664 (hydrazide C=O), $1593(\mathrm{C}=\mathrm{N}), 1239$ (C-F); ${ }^{1} \mathrm{HNMR}$ $\left(400 \mathrm{MHz}, \mathrm{DMSO}-\mathrm{d}_{6}, \delta \mathrm{ppm}\right): 1.66$ (br.s, $4 \mathrm{H}, 2 \mathrm{CH}_{2}$ of tetrahydronaphthalene), $2.67\left(\mathrm{~m}, 4 \mathrm{H}, 2 \mathrm{CH}_{2}\right.$ of tetrahydronaphthalene), 5.62, $5.09\left(2 \mathrm{~s}, 2 \mathrm{H}, \mathrm{OCH}_{2}\right.$ trans and cis conformers), 7.05, $7.10(2 \mathrm{~d}, \mathrm{~J}=8.0 \mathrm{~Hz}, 8.0 \mathrm{~Hz} 1 \mathrm{H}$, C-4 proton of tetrahydronaphthalene, trans/cis conformers), 7.47 (d, J = 8 Hz, 5H, Ar-H), 7.71-7.88 (m, 7H, Ar- H + pyridine-H5), 8.12, $8.33(2 \mathrm{~s}, 1 \mathrm{H}, \mathrm{N}=\mathrm{CH}$ trans/cis conformers), 11.77, 11.95 (2s, $1 \mathrm{H}, \mathrm{NH}$ exchangeable with $\mathrm{D}_{2} \mathrm{O}$ trans/cis conformers); ${ }^{13} \mathrm{C}$ NMR (101 MHz, DMSO) $\delta: 22.40,22.48\left(2 \mathrm{CH}_{2}\right), 28.64\left(2 \mathrm{CH}_{2}\right), 63.50,65.59$ $\left(\mathrm{OCH}_{2}\right.$, trans/cis conformers), $113.49(\mathrm{CN}), 128.84,129.35$ (C-4 of tetrahydronaphthalene, trans/cis conformers), 139.97, 143.89 ( $\mathrm{N}=\underline{\mathrm{CH}}$ trans/cis conformers), (91.24, 103.54, 115.75, 115.97, 124.44, 129.73, 131.07, 131.16, 133.45, 133.99, 135.11, 137.08, 155.24, 157.08, 161.08, 161.71, 163.22 ) (23, Ar-C), 168.68 (hydrazide $\mathrm{C}=0) ; \mathrm{MS}, \mathrm{m} / \mathrm{z}(\%): 504.48\left(\mathrm{M}^{+}, 11\right), 503.18\left(\mathrm{M}^{+}-1,8\right), 77.13$ (73), 63.09 (100), 62.13 (42.31). Analysis calcd.for $\mathrm{C}_{31} \mathrm{H}_{25} \mathrm{FN}_{4} \mathrm{O}_{2}(504.57) \mathrm{C}, 73.79 ; \mathrm{H}, 4.99 ; \mathrm{F}, 3.77 ; \mathrm{N}, 11.10$; Found: $\mathrm{C}, 73.68 ; \mathrm{H}, 4.87 ; \mathrm{F}, 3.72 ; \mathrm{N}$, 11.21. 
N'-(4-Bromobenzylidene)-2-((3-cyano-4-(4-fluorophenyl)-6-(5,6,7,8-tetrahydronaphthalen-2-yl)pyridin-2-

yl)oxy)acetohydrazide (8c). Yield 57\%; light beige crystals; m.p. $236-2372{ }^{\circ} \mathrm{C}$, the ratio of trans/cis conformers: 78/22. IR spectrum ( $\mathrm{KBr}, \mathrm{cm}^{-1}$ ): $3212(\mathrm{NH}), 2925$ ( $\mathrm{CH}$, alicyclic), $2221(\mathrm{CN}), 1677$ (hydrazide $\left.\mathrm{C}=\mathrm{O}\right), 1600(\mathrm{C}=\mathrm{N})$, 1240 (C-F); ${ }^{1} \mathrm{HNMR}$ (300MHz, DMSO- $\mathrm{d}_{6}, \delta \mathrm{ppm}$ ): 1.66 (br.s, 4H, 2CH $\mathrm{CH}_{2}$ tetrahydronaphthalene), $2.67(\mathrm{~m}, 4 \mathrm{H}$, $2 \mathrm{CH}_{2}$ of tetrahydronaphthalene), 5.61, $5.09\left(2 \mathrm{~s}, 2 \mathrm{H}, \mathrm{OCH}_{2}\right.$ trans/cis conformers), 7.04, $7.08(2 \mathrm{~d}, J 8.4 \mathrm{~Hz}, 8.4 \mathrm{~Hz}$ $1 \mathrm{H}, \mathrm{C}-4$ proton of tetrahydronaphthalene, trans/cis conformers), $7.46(\mathrm{t}, \mathrm{J} 8.8 \mathrm{~Hz}, 2 \mathrm{H}, \mathrm{Ar}-\mathrm{H}), 7.65-7.84(\mathrm{~m}, 9 \mathrm{H}$, $\mathrm{Ar}-\mathrm{H}+$ Pyridine-H5), 8.09, 8.31 (2s, $1 \mathrm{H}, \mathrm{N}=\mathrm{CH}$ trans/cis conformers), 11.78, $11.92(2 \mathrm{~s}, 1 \mathrm{H}, \mathrm{NH}$ exchangeable with $\mathrm{D}_{2} \mathrm{O}$ trans/cis conformers); ${ }^{13} \mathrm{C} N M R(300 \mathrm{MHz}, \mathrm{DMSO}) \delta: 22.31,22.38\left(2 \mathrm{CH}_{2}\right), 28.56,28.69\left(2 \mathrm{CH}_{2}\right) 63.42$, $64.97\left(\mathrm{OCH}_{2}\right.$, trans/cis conformers), $115.06(\mathrm{CN}), 128.59,128.77$ (C-4 of tetrahydronaphthalene, trans/cis conformers), 142.66, $145.92(\mathrm{~N}=\underline{\mathrm{CH}}$, trans/cis conformers), (91.42, 113.46, 115.58, 115.87, 123.06, 124.33, $127.81,129.21,130.89,131.01,131.70,133.42,137.04,139.89,155.15,157.07,161.42,163.15,164.71)(23$, Ar-C), 168.59 (hydrazide $\mathrm{C}=0$ ); $\mathrm{MS}, \mathrm{m} / \mathrm{z}(\%): 584.11\left(\mathrm{M}^{+}+1,4.4\right), 583.11\left(\mathrm{M}^{+}, 6\right), 582.09\left(\mathrm{M}^{+}-1,2\right), 385.08(100)$, 357.12 (41), 344.11 (42).Analysis calcd.for: $\mathrm{C}_{31} \mathrm{H}_{24} \mathrm{BrFN}_{4} \mathrm{O}_{2}$ (583.46): C, 63.82; $\mathrm{H}, 4.15 ; \mathrm{Br}, 13.69 ; \mathrm{F}, 3.26 ; \mathrm{N}$, 9.60; Found C, 63.79; $\mathrm{H}, 4.05 ; \mathrm{Br}, 13.58 ; \mathrm{F}, 3.23 ; \mathrm{N}, 9.79$.

\section{N'-(4-Chlorobenzylidene)-2-((3-cyano-4-(4-fluorophenyl)-6-(5,6,7,8-tetrahydronaphthalen-2-yl)pyridin-2-}

yl)oxy)acetohydrazide (8d). Yield 67\%; beige crystals; m.p. $231-232{ }^{\circ} \mathrm{C}$, the ratio of trans/cis conformers: 72/28; IR spectrum ( $\left.\mathrm{KBr}, \mathrm{cm}^{-1}\right)$ : $3208(\mathrm{NH}), 2929$ ( $\mathrm{CH}$, alicyclic), $2221(\mathrm{CN}), 1677$ (hydrazide $\left.\mathrm{C}=0\right), 1593(\mathrm{C}=\mathrm{N})$, 1239 (C-F); ${ }^{1} \mathrm{HNMR}\left(400 \mathrm{MHz}, \mathrm{DMSO}-\mathrm{d}_{6}, \delta \mathrm{ppm}\right): 1.67\left(\mathrm{~m}, 4 \mathrm{H}, 2 \mathrm{CH}_{2}\right.$ of tetrahydronaphthalene), $2.65(\mathrm{~m}, 4 \mathrm{H}$, $4 \mathrm{CH}_{2}$ of tetrahydronaphthalene), 5.61, $5.09\left(2 \mathrm{~s}, 2 \mathrm{H}, \mathrm{OCH}_{2}\right.$ trans/cis conformers), 7.06, $7.11(2 \mathrm{~d}, J 8.0 \mathrm{~Hz}, 8.0 \mathrm{~Hz}$ $1 \mathrm{H}, \mathrm{C}-4$ proton of tetrahydronaphthalene, trans/cis conformers), $7.31(\mathrm{t}, J 8.8 \mathrm{~Hz}, 2 \mathrm{H}, \mathrm{Ar}-\mathrm{H}), 7.46(\mathrm{t}, J 8.8 \mathrm{~Hz}$, $2 \mathrm{H}, \mathrm{Ar}-\mathrm{H}), 7.79-7.86(\mathrm{~m}, 7 \mathrm{H}, \mathrm{Ar}-\mathrm{H}+$ pyridine-H5), 8.11, $8.33(2 \mathrm{~s}, 1 \mathrm{H}, \mathrm{N}=\mathrm{CH}$ trans/cis conformers) $, 11.78,11.96$ (2s, $1 \mathrm{H}, \mathrm{NH}$ exchangeable with $\mathrm{D}_{2} \mathrm{O}$ trans/cis conformers); ${ }^{13} \mathrm{C} \mathrm{NMR}(101 \mathrm{MHz}, \mathrm{DMSO}) \delta: 21.07,22.40\left(2 \mathrm{CH}_{2}\right)$, $25.83\left(2 \mathrm{CH}_{2}\right), 64.77,65.81\left(\mathrm{OCH}_{2}\right.$ trans/cis conformers), 113.70 (CN), $128.49,128.93$ (C-4 of tetrahydronaphthalene, trans/cis conformers), 142.40, 145.18 ( $\mathrm{N}=\underline{\mathrm{CH}}$, trans/cis conformers), (91.86, 109.74, $115.98,122.86,129.35,130.25,131.16,133.45,134.77,135.60,136.79,156.87,158.47,163.86)(22, \operatorname{Ar}-\mathrm{C})$, 168.55 (hydrazide $\mathrm{C}=0) ; \mathrm{MS}, \mathrm{m} / \mathrm{z}(\%): 541.23\left(\mathrm{M}^{+}+2,5\right), 539.13\left(\mathrm{M}^{+}, 16\right), 123.13(23.63), 59.14(18.54), 10.15$ (100), Analysis calcd. for: $\mathrm{C}_{31} \mathrm{H}_{24} \mathrm{ClFN}_{4} \mathrm{O}_{2}$ (539.01): C, 69.08; $\mathrm{H}, 4.49 ; \mathrm{Cl}, 6.58 ; \mathrm{F}, 3.52 ; \mathrm{N}, 10.39$; Found: $\mathrm{C}, 68.96$; $\mathrm{H}, 4.38 ; \mathrm{Cl}, 6.46 ; \mathrm{F}, 3.48 ; \mathrm{N}, 10.42$.

2-((3-Cyano-4-(4-fluorophenyl)-6-(5,6,7,8-tetrahydronaphthalen-2-yl)pyridin-2-yl)oxy)-N'-(4-

cyanobenzylidene)acetohydrazide (8e). Yield 70\%; pale yellow crystals; m.p. $230-231{ }^{\circ} \mathrm{C}$ the ratio of trans/cis conformers: 70/30; IR spectrum ( $\left.\mathrm{KBr}, \mathrm{cm}^{-1}\right)$ : $3182(\mathrm{NH}), 2929(\mathrm{CH}$, alicyclic), $2224(\mathrm{CN}), 1675$ (hydrazide C=O),

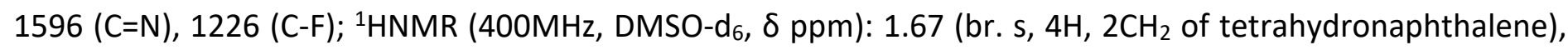
$2.67\left(\mathrm{~m}, 4 \mathrm{H}, 2 \mathrm{CH}_{2}\right.$ of tetrahydronaphthalene), 5.64, $5.12\left(2 \mathrm{~s}, 2 \mathrm{H}, \mathrm{OCH}_{2}\right.$ trans/cis conformers), $7.05,7.10(2 \mathrm{~d}$, $J=8.0 \mathrm{~Hz}, 8.0 \mathrm{~Hz} 1 \mathrm{H}, \mathrm{C}-4$ proton of tetrahydronaphthalene, trans/cis conformers),7.45 (t, J 8.7Hz, 2H, Ar-H), 7.79-7.97 (m, 9H, Ar-H + pyridine-H5), 8.16, 8.39 (2s, $1 \mathrm{H}, \mathrm{N}=\mathrm{CH}$ trans/cis conformers), 12.01, $12.19(2 \mathrm{~s}, 1 \mathrm{H}, \mathrm{NH}$ exchangeable with $\mathrm{D}_{2} \mathrm{O}$ trans/cis conformers); ${ }^{13} \mathrm{C} \mathrm{NMR} \mathrm{(101} \mathrm{MHz,} \mathrm{DMSO)} \delta: 22.38,22.46\left(2 \mathrm{CH}_{2}\right), 28.63,28.77$ $\left(2 \mathrm{CH}_{2}\right) ; 62.77,63.47\left(\mathrm{OCH}_{2}\right.$ trans/cis conformers), $113.58(\mathrm{CN}), 118.62$ (CN), 127.42, 127.58 (C-4 of tetrahydronaphthalene, trans/cis conformers), 139.97, 141.99 ( $\mathrm{N}=\underline{\mathrm{CH}}$ trans/cis conformers), $(91.43,111.80$, $115.95,118.62,116.66,129.34,131.06,131.14,132.13,132.73,133.43,137.05,138.43,155.22,157.07$, 162.05, 163.17) (23C, Ar-C), 169.04 (hydrazide $C=0) ; M S, m / z(\%): 531.30\left(M^{+}+2,2\right), 530.36\left(M^{+}+1,3\right), 529.48$ $\left(\mathrm{M}^{+}, 6\right), 528.53\left(\mathrm{M}^{+}-1,2\right), 431.20(30), 368.43(58), 358.22$ (100) , $357(70), 327.30$ (58); Analysis calcd. for: $\mathrm{C}_{32} \mathrm{H}_{24} \mathrm{FN}_{5} \mathrm{O}_{2}$ (529.58): C, 72.58; $\mathrm{H}, 4.57 ; \mathrm{F}, 3.59 ; \mathrm{N}, 13.22$; Found: $\mathrm{C}, 72.47 ; \mathrm{H}, 4.49 ; \mathrm{F}, 3.53 ; \mathrm{N}, 13.31$.

2-((3-Cyano-4-(4-fluorophenyl)-6-(5,6,7,8-tetrahydronaphthalen-2-yl)pyridin-2-yl)oxy)-N'-(4-methoxybenzylidene)acetohydrazide (8f). Yield 56\%; colorless powder; m.p. $222-223{ }^{\circ} \mathrm{C}$, the ratio of trans/cis 
conformers: 75/25; IR spectrum $\left(\mathrm{KBr}, \mathrm{cm}^{-1}\right)$ : $3204(\mathrm{NH}), 2928$ (CH, alicyclic), 2221 (CN), 1681 (hydrazide C=O), $1603(\mathrm{C}=\mathrm{N}), 1250(\mathrm{C}-\mathrm{F}) ;{ }^{1} \mathrm{HNMR}\left(400 \mathrm{MHz}, \mathrm{DMSO}-\mathrm{d}_{6}, \delta \mathrm{ppm}\right): 1.69$ (br.s, $4 \mathrm{H}, 2 \mathrm{CH}_{2}$ of tetrahydronaphthalene), $2.69\left(\mathrm{~m}, 4 \mathrm{H}, 2 \mathrm{CH}_{2}\right.$ of tetrahydronaphthalene), $3.81\left(\mathrm{~s}, 3 \mathrm{H}, \mathrm{OCH}_{3}\right), 5.39,5.07\left(2 \mathrm{~s}, 2 \mathrm{H}, \mathrm{OCH}_{2}\right.$ trans/cis conformers), 7.00-7.13 (m, 3H, C-4 proton of tetrahydronaphthalene trans/cis conformers $+\mathrm{Ar}-\mathrm{H}), 7.013$, 7.061, 7.113 (3d, 3H, C4-proton of tetrahydronaphthalene trans/cis conformers + Ar-H), 7.42-7.91 (m, 9H, Ar-H + Pyridine-H5), 8.07, 8.26 (2s, 1H, N=CH trans/cis conformers), 11.64, 11.80 (2s, 1H, NH exchangeable with $\mathrm{D}_{2} \mathrm{O}$ trans/cis conformers); ${ }^{13} \mathrm{C}$ NMR $(101 \mathrm{MHz}, \mathrm{DMSO}) \delta: 22.19\left(2 \mathrm{CH}_{2}\right), 29.50\left(2 \mathrm{CH}_{2}\right), 56.07\left(\mathrm{OCH}_{3}\right), 65.93$, $66.91\left(\mathrm{OCH}_{2}\right.$ trans/cis conformers), $114.80(\mathrm{CN}), 128.86,128.92$ (C-4 of tetrahydronaphthalene, trans/cis conformers), 140.09, $142.36(\mathrm{~N}=\underline{\mathrm{CH}}$ trans/cis conformers), (89.38, 106.08, 114.17, 116.73, 122.38, 126.46, $129.32,130.34,133.38,134.00,136.63,156.93,157.77,162.75,163.64,164.06$ ) (23, Ar-C), 168.07 (hydrazide $\mathrm{C}=0) ; \mathrm{MS}, \mathrm{m} / \mathrm{z}(\%): 536.47\left(\mathrm{M}^{+}+2,83\right), 534.41\left(\mathrm{M}^{+}, 90\right), 530.29$ (28), 503.20 (39), 496.68 (35), 491.29 (44), 464.09 (45), 459.08 (46), 428.97 (37), 416.78 (33), 360.86 (44), 283.00 (55), 265.46 (72), 150.00 (39), 117.89 (29), 91.84 (43), 65.40 (100); Analysis calcd.for $\mathrm{C}_{32} \mathrm{H}_{27} \mathrm{FN}_{4} \mathrm{O}_{3}$ (534.59): C, 71.90; $\mathrm{H}, 5.09 ; \mathrm{F}, 3.55 ; \mathrm{N}, 10.48$; Found: $C, 71.82 ; H, 5.03 ; F, 3.49 ; N, 10.57$.

General procedure for synthesis of thiazolidinone 11a and 11c-f. A solution of Schiff bases (8a and 8c-f) (0.001 mol), and thioglycolic acid (9) (0.165 g; $0.0015 \mathrm{~mol})$, in dry benzene (50) $\mathrm{mL}$ was heated at refluxed for $6 \mathrm{~h}$. Progress of the reaction was checked by TLC using benzene-ether as eluent. After evaporation of the solvent under reduced pressure, the resulting viscous liquid was treated with saturated sodium bicarbonate solution to remove unreacted thioglycolic acid. The product separated out was washed with water, dried and recrystallized from ethanol to afford compounds 11a and 11c-f.

2-((3-Cyano-4-(4-fluorophenyl)-6-(5,6,7,8-tetrahydronaphthalen-2-yl)pyridin-2-yl)oxy)-N-(2-(4-

fluorophenyl)-4-oxothiazolidin-3-yl)acetamide (11a). Yield 65\%; beigh crystals; m.p. 240-242 ${ }^{\circ} \mathrm{C}$; IR spectrum $\left(\mathrm{KBr}, \mathrm{cm}^{-1}\right)$ : $3439(\mathrm{NH}), 2924(\mathrm{CH}$, alicyclic), $2223(\mathrm{CN}), 1724$ (C=O of 4-thiazolidinone ring), 1677 (C=O amide), $1600(\mathrm{C}=\mathrm{N}), 1228(\mathrm{C}-\mathrm{F}) ;{ }^{1} \mathrm{H}$ NMR $\left(400 \mathrm{MHz}, \mathrm{DMSO}-\mathrm{d}_{6}, \delta \mathrm{ppm}\right): 1.77,2.79$ (2 br.s, 4H, 4H, 4CH $\mathrm{CH}_{2}$ tetrahydronaphthalene), 3.73, $3.89\left(2 \mathrm{~d}, 2 \mathrm{H}\right.$, thiazolidinone- $\left.\mathrm{CH}_{2}\right), 5.03,5.10(2 \mathrm{~d}, 2 \mathrm{H}, 2-$ methylene- $\mathrm{H}$ of $\mathrm{OCH}$ ), $5.74(\mathrm{~s}, 1 \mathrm{H}$, thiazolidinone-H-2), 7.02-7.11 (m, 2H, Ar-H), 7.32 -7.48 (m, 4H, Ar- $\mathrm{H}), 7.70-7.95(\mathrm{~m}, 6 \mathrm{H}, \mathrm{Ar}-\mathrm{H}+$ pyridine-H5), $10.63\left(\mathrm{~s}, 1 \mathrm{H}, \mathrm{NH}\right.$ exchangeable with $\left.\mathrm{D}_{2} \mathrm{O}\right) ;{ }^{13} \mathrm{C} N M R(101 \mathrm{MHz}, \mathrm{DMSO}) \delta: 22.61\left(2 \mathrm{CH}_{2}\right), 28.77$

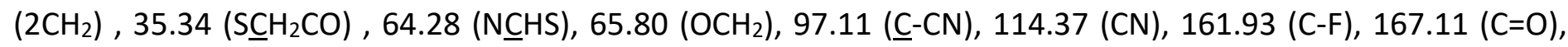
168.56 (C=O), (104.46, 115.77, 124.53 , 127.38, 129.40, 131.02, 132.06, 133.17, $134,135.12,136.01,157.35$, 157.76 , 163.15, 164.89 ) (21, Ar-C); MS, m/z (\%): 596.65 ( $\left.\mathrm{M}^{+}, 8\right), 97.17$ (8.), 85.17 (26.84) , 71.15 (82.42), 57.14 (100); Analysis calcd. for: $\mathrm{C}_{33} \mathrm{H}_{26} \mathrm{~F}_{2} \mathrm{~N}_{4} \mathrm{O}_{3} \mathrm{~S}$ (596.65): C, 66.43; $\mathrm{H}, 4.39 ; \mathrm{F}, 6.37 ; \mathrm{N}, 9.39 ; \mathrm{S}, 5.37$; found: C, 66.38; H,4.28; F, 6.17; N, 9.48; S, 5.24.

\section{N-(2-(4-Bromophenyl)-4-oxothiazolidin-3-yl)-2-((3-cyano-4-(4-fluorophenyl)-6-(5,6,7,8-tetrahydro-}

naphthalen-2-yl)pyridin-2-yl)oxy)acetamide (11c). Yield 66\%; light beigh crystals; m.p. $246-248{ }^{\circ} \mathrm{C}$; IR spectrum ( $\mathrm{KBr}, \mathrm{cm}^{-1}$ ): $3441(\mathrm{NH}), 2925$ ( $\mathrm{CH}$, alicyclic), $2220(\mathrm{CN}), 1715$ (C=O of 4-thiazolidinone ring), 1675 (C=O amide), 1598 (C=N), 1230 (C-F); ${ }^{1} \mathrm{H}$ NMR (400MHz, DMSO-d,$\left.\delta p p m\right): 1.75$ (br. s, 4H, 2CH $\mathrm{CH}_{2}$ tetrahydronaphthalene), 2.79 (br.s, $4 \mathrm{H}, 2 \mathrm{CH}_{2}$ of tetrahydronaphthalene), 3.73, 3.89 (2d, 2H, thiazolidinone$\left.\mathrm{CH}_{2}\right), 5.04,5.11\left(2 \mathrm{~d}, 2 \mathrm{H}, 2-\right.$ methylene- $\mathrm{H}$ of $\left.\mathrm{OCH}_{2}\right), 5.72(\mathrm{~s}, 1 \mathrm{H}$, thiazolidinone-H-2), $7.08(\mathrm{~d}, J 8.0 \mathrm{~Hz}, 1 \mathrm{H}, \mathrm{Ar}-\mathrm{H})$, $7.23(\mathrm{~d}, J 8.0 \mathrm{~Hz}, 2 \mathrm{H}, \mathrm{Ar}-\mathrm{H}), 7.38-7.48(\mathrm{~m}, 4 \mathrm{H}, \mathrm{Ar}-\mathrm{H}), 7.74-7.95(\mathrm{~m}, 5 \mathrm{H}, \mathrm{Ar}-\mathrm{H}+$ pyridine-H5), $10.72(\mathrm{~s}, 1 \mathrm{H}, \mathrm{NH}$ exchangeable with $\left.\mathrm{D}_{2} \mathrm{O}\right) ;{ }^{13} \mathrm{C}$ NMR (101 MHz, DMSO) $\delta: 22.53\left(2 \mathrm{CH}_{2}\right), 28.80\left(2 \mathrm{CH}_{2}\right), 34.65\left(\mathrm{CH}_{2}\right), 60.82(\mathrm{~N} \underline{\mathrm{CHS}})$, $63.59\left(\mathrm{OCH}_{2}\right), 115.07$ (CN), (91.65, 107.47, 115.77, 120.60, 125.01, 127.92, 129.28, 130.14, 131.01, 131.34, $133.21,133.33,134.90,136.43,138.28,155.01,157.30,162.61,164.62)(22, \mathrm{Ar}-\mathrm{C}) 166.55(\mathrm{C}=0), 168.87(\mathrm{C}=0)$; MS, m/z (\%): $656.18\left(\mathrm{M}^{+}, 6\right), 440.16$ (5), 385.14 (5), 357.94 (9), 344.18 (19), 257.94 (9), 184.01 (19), 89.07 (65), 
77.09 (87), 76.09 (94.18), 75.09 (100); Analysis calcd. for: $\mathrm{C}_{33} \mathrm{H}_{28} \mathrm{BrFN}_{4} \mathrm{O}_{3} \mathrm{~S}$ (657.56): C, 60.28; $\mathrm{H}, 3.99 ; \mathrm{Br}, 12.15$; F, 2.89; N, 8.52; S, 4.88; found: C, 60.19; H, 3.89; Br, 12.11; F, 2.78; N, 8.61; S, 4.83 .

\section{$\mathbf{N}$-(2-(4-Chlorophenyl)-4-oxothiazolidin-3-yl)-2-((3-cyano-4-(4-fluorophenyl)-6-(5,6,7,8-}

tetrahydronaphthalen-2-yl)pyridin-2-yl)oxy)acetamide (11d). Yield 62\%; light beigh crystals; m.p. $240-242{ }^{\circ} \mathrm{C}$; IR spectrum ( $\mathrm{KBr}, \mathrm{cm}^{-1}$ ): $3439(\mathrm{NH}), 2925$ (CH, alicyclic), 2220 (CN), 1711 (C=O of 4-thiazolidinone ring), 1677 (C=O amide), 1600 (C=N), 1231 (C-F); ${ }^{1} \mathrm{H}$ NMR (400 MHz, DMSO-d $6, \delta$ ppm): 1.77 (br.s, 4H, 2CH $\mathrm{H}_{2}$ of tetrahydronaphthalene), 2.79 (br.s, $4 \mathrm{H}, 2 \mathrm{CH}_{2}$ of tetrahydronaphthalene), 3.74, 3.89 (2d, 2H, thiazolidinone$\left.\mathrm{CH}_{2}\right), 5.06,5.09\left(2 \mathrm{~d}, 2 \mathrm{H}, 2-\right.$ methylene-H of $\left.\mathrm{OCH}_{2}\right), 5.74(\mathrm{~s}, 1 \mathrm{H}$, thiazolidinone-H-2), $7.09(\mathrm{~d}, J 8.0 \mathrm{~Hz}, 1 \mathrm{H}, \mathrm{Ar}-\mathrm{H})$, 7.27-7.30 (m, 3H, Ar-H), 7.46 (t, J $8.0 \mathrm{~Hz}, 3 \mathrm{H}, \mathrm{Ar}-\mathrm{H}), 7.75-7.84(\mathrm{~m}, 4 \mathrm{H}, \mathrm{Ar}-\mathrm{H}), 7.90$ (s, 1H, pyridine-H5), 10.67 (s, $1 \mathrm{H}, \mathrm{NH}$ exchangeable with $\left.\mathrm{D}_{2} \mathrm{O}\right) ;{ }^{13} \mathrm{C} \mathrm{NMR}(101 \mathrm{MHz}, \mathrm{DMSO}) \delta: 22.53\left(2 \mathrm{CH}_{2}\right), 28.77\left(2 \mathrm{CH}_{2}\right), 32.71\left(\mathrm{~S} \underline{\mathrm{CH}} \mathrm{CO}_{2}\right)$, 62.00 (NCHS), $69.33\left(\mathrm{OCH}_{2}\right), 97.80$ ( $\left.\underline{\mathrm{C}}-\mathrm{CN}\right), 114.33$ (CN), 132.97 (C-Cl), $166.62(\mathrm{C}=0), 168.21$ (C=0), (106.72, $116.11,121.83,126.40,128.43,129.43,131.25,133.17,134.22$, 136.22 , $140.98,155.91,157.29,162.74$, 165.02 ) (21, Ar-C); MS, m/z (\%): 613.99 (M+, 14), 210.15 (72.02), 123.12 (23),.71.15 (36.49), 69.18 (100); Analysis calcd. for : $\mathrm{C}_{33} \mathrm{H}_{26} \mathrm{ClFN}_{4} \mathrm{O}_{3} \mathrm{~S}$ (613.10): $\mathrm{C}, 64.65 ; \mathrm{H}, 4.27 ; \mathrm{Cl}, 5.78 ; \mathrm{F}, 3.10 ; \mathrm{N}, 9.14 ; \mathrm{S}, 5.23 ;$ found: $\mathrm{C}, 64.58$; $\mathrm{H}, 4.19 ; \mathrm{Cl}, 5.69 ; \mathrm{F}, 2.99 ; \mathrm{N}, 9.26 \mathrm{~S}, 5.19$.

2-((3-Cyano-4-(4-fluorophenyl)-6-(5,6,7,8-tetrahydronaphthalen-2-yl)pyridin-2-yl)oxy)-N-(2-(4-cyanophenyl)4-oxothiazolidin-3-yl)acetamide (11e). Yield 60\%; light green crystals; m.p. 190-192 ${ }^{\circ} \mathrm{C}$; IR spectrum $\left(\mathrm{KBr}, \mathrm{cm}^{-1}\right)$ : $3435(\mathrm{NH}), 2928$ ( $\mathrm{CH}$, alicyclic), $2224(\mathrm{CN}), 1729$ (C=O of 4-thiazolidinone ring), 1685 ( $\mathrm{C}=\mathrm{O}$ amide), 1595 (C=N), 1233 (C-F); ${ }^{1} \mathrm{H}$ NMR (400MHz, DMSO-d 6 , $\left.\delta p p m\right): 1.75$ (br. s, $4 \mathrm{H}, 2 \mathrm{CH}_{2}$ of tetrahydronaphthalene), 2.77 (br. s, $4 \mathrm{H}, 2 \mathrm{CH}_{2}$ of tetrahydronaphthalene) 3.75, $3.93\left(2 \mathrm{~d}, 2 \mathrm{H}\right.$, thiazolidinone- $\left.\mathrm{CH}_{2}\right), 5.05,5.09$ (2d, 2-methylene- $\mathrm{H}$ of $\left.\mathrm{OCH}_{2}\right), 5.83(\mathrm{~s}, 1 \mathrm{H}$, thiazolidinone-H-2), $7.05(\mathrm{~d}, J 8.1 \mathrm{~Hz}, 1 \mathrm{H}, \mathrm{Ar}-\mathrm{H}), 7.45(\mathrm{~d}, J 8.0 \mathrm{~Hz}, 4 \mathrm{H}, \mathrm{Ar}-\mathrm{H}), 7.62-7.66(\mathrm{~m}$, $2 \mathrm{H}, \mathrm{Ar}-\mathrm{H}), 7.74-7.94\left(\mathrm{~m}, 5 \mathrm{H}, \mathrm{Ar}-\mathrm{H}+\right.$ pyridine-H5), $10.82\left(\mathrm{~s}, 1 \mathrm{H}, \mathrm{NH}\right.$ exchangeable with $\left.\mathrm{D}_{2} \mathrm{O}\right) ;{ }^{13} \mathrm{CNMR}(101 \mathrm{MHz}$,

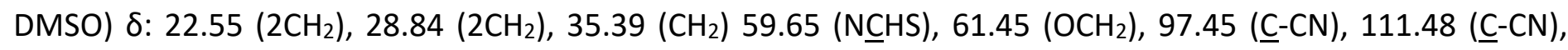
115. 76 (CN), 121.23 (CN), 168.76 (2 C=O), (101.66, 117.26, 123.91, 127.58, 128.20, 130.62, 132.33, 134.63, 136.42, 137.93, 157.77, 161.70, 164.75, 166.60), (21, Ar-C); MS, m/z (\%): $605.69\left(M^{+}+2,3\right), 603.17\left(M^{+}, 10\right)$, 430.24 (76), 357.21 (100), 102.13 (61), 76.03 (88); Analysis calcd. for: $\mathrm{C}_{34} \mathrm{H}_{28} \mathrm{FN}_{5} \mathrm{O}_{3} \mathrm{~S}$ (603.67) C, 67.65; $\mathrm{H}, 4.34$; F, 3.15; N, 11.60; S, 5.31; found: C, 67.50; H, 4.22; F, 3.05; N, 11.68; S, 5.22.

\section{2-((3-Cyano-4-(4-fluorophenyl)-6-(5,6,7,8-tetrahydronaphthalen-2-yl)pyridin-2-yl)oxy)-N-(2-(4-}

methoxyphenyl)-4-oxothiazolidin-3-yl)acetamide (11f). Yield 73\%; light beigh crystals; m.p. $260-262^{\circ} \mathrm{C}$; IR spectrum ( $\mathrm{KBr}, \mathrm{cm}^{-1}$ ): $3437(\mathrm{NH}), 2919(\mathrm{CH}$, alicyclic), $2221(\mathrm{CN}), 1712$ (C=O of 4-thiazolidinone ring), 1678 (C=O amide), 1608 (C=N), 1231 (C-F); ${ }^{1} \mathrm{H}$ NMR (400MHz, DMSO-d,$\left.\delta p p m\right): 1.77,2.79$ (2 br.s, 4H, 4H, 4CH 2 of tetrahydronaphthalene), $3.69\left(\mathrm{~s}, 3 \mathrm{H}, \mathrm{OCH}_{3}\right), 3.77,3.85\left(2 \mathrm{~d}, 2 \mathrm{H}\right.$, thiazolidinone- $\left.\mathrm{CH}_{2}\right), 5.00,5.15$ (2d, 2methylene-H of $\left.\mathrm{OCH}_{2}\right), 5.68(\mathrm{~s}, 1 \mathrm{H}$, thiazolidinone-H-2), $6.79(\mathrm{~d}, J 8.0 \mathrm{~Hz}, 1 \mathrm{H}, \mathrm{Ar}-\mathrm{H}), 7.12,7.22(2 \mathrm{~d}, J 8.0 \mathrm{~Hz}, J$ $8.0 \mathrm{~Hz}, 2 \mathrm{H}, \mathrm{Ar}-\mathrm{H}), 7.47(\mathrm{~d}, \mathrm{~J} 8.0 \mathrm{~Hz}, 3 \mathrm{H}, \mathrm{Ar}-\mathrm{H}), 7.69-7.92(\mathrm{~m}, 6 \mathrm{H}, \mathrm{Ar}-\mathrm{H}+$ pyridine-H5), 10.57 (s, $1 \mathrm{H}, \mathrm{NH}$ exchangeable with $\left.\mathrm{D}_{2} \mathrm{O}\right) ;{ }^{13} \mathrm{C}$ NMR $(101 \mathrm{MHz}, \mathrm{DMSO}) \delta: 22\left(2 \mathrm{CH}_{2}\right), 29.72\left(2 \mathrm{CH}_{2}\right), 32.77\left(\mathrm{SCH}_{2} \mathrm{CO}\right), 56.56\left(\mathrm{OCH}_{3}\right)$, 65.38 (NCHS), $68.15\left(\mathrm{OCH}_{2}\right), 114.79(\mathrm{CN}), 166.62$ (C=O), $168.55(\mathrm{C}=\mathrm{O}),(91.09,110.31,113.76,116.72,119.97$, 128.40, 129.52, 130.55, 131.65, 133.80, 134.90, 135.11, 136.63, 156.95, 157.15, 158.00, 162.54, 164.27) (22, Ar-C); MS, m/z (\%): $608.69\left(\mathrm{M}^{+}, 10\right), 91.15(2), 85.19$ (5), 71.18 (23), 57.15 (100); Analysis calcd. for $: \mathrm{C}_{34} \mathrm{H}_{29} \mathrm{FN}_{4} \mathrm{O}_{4} \mathrm{~S}$ (608.69): C, 67.09; H, 4.80; F, 3.12; N, 9.20; S, 5.27;found: C, 66.98; H, 4.75; F, 3.05; N, 9.29; S, 5.23 .

2-((3-Cyano-4-(4-fluorophenyl)-6-(5,6,7,8-tetrahydronaphthalen-2-yl)pyridin-2-yl)oxy)-N'-(2-oxoindolin-3ylidene)acetohydrazide (13). A mixture of the hydrazide $7(0.416 \mathrm{~g}, 1 \mathrm{mmol})$ and isatin $12(0.147 \mathrm{~g}, 1 \mathrm{mmol}) \mathrm{in}$ absolute ethanol $(20 \mathrm{~mL})$ containing glacial acetic acid $(0.5 \mathrm{~mL})$ was heated at reflux for $10 \mathrm{~h}$. The precipitate 
formed was collected by filtration while hot, washed with hot ethanol, dried and recrystallized from AcOH to afford compound 13.

Yield: 86\%; yellow crystals; m.p. 288-300 ${ }^{\circ} \mathrm{C}$; IR spectrum $\left(\mathrm{KBr}, \mathrm{cm}^{-1}\right): 3427,3212(\mathrm{NH}), 2926(\mathrm{CH}$, alicyclic), 2228 (CN 1709 ( $\mathrm{C}=\mathrm{O}$ of isatin ring), 1657 ( $\mathrm{C}=\mathrm{O}$ amide), 1622 (C=N) 1228 (C-F); ${ }^{1} \mathrm{H}$ NMR (DMSO-d,$\delta$ ppm): 1.66 (br.s, 4H, 2CH tetrahydronaphthalene), $2.68\left(\mathrm{~m}, 4 \mathrm{H}, 2 \mathrm{CH}_{2}\right.$ of tetrahydonaphthalene), 5.30, 5.78 (br. $2 \mathrm{~s}, 2 \mathrm{H}, \mathrm{OCH}_{2}$ trans/c conformers), 6.97-7.13 (m, 3H, Ar-H), 7.38-7.49 (m, 4H, Ar-H), 7.82-7.87 (m, 5H, Ar-H+Pyridine-H5), 11.35 (s, $1 \mathrm{H}, \mathrm{NH}$ isatin exchangeable with $\left.\mathrm{D}_{2} \mathrm{O}\right), 12.78,13.40$ (br. $2 \mathrm{~s}, 1 \mathrm{H}$, NH exchangeable with $\mathrm{D}_{2} \mathrm{O}$ trans/cis conformers); ${ }^{13} \mathrm{C} \mathrm{NMR} \mathrm{(10}$

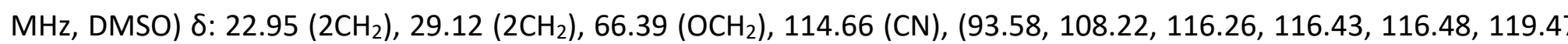
$123.20,123.67,128.45,129.80,131.69,133.59,133.84,135.17,136.13,143.04,155.90,156.65,163.09,164.77)(2$ Ar-C) 167.90, 168.75 (2 C=O); MS, m/z (\%): $545.57\left(\mathrm{M}^{+}, 6\right), 385.09$ (76), 384.09 (30), 358.10 (100), 357.07 (83); Analys calcd. for $\mathrm{C}_{32} \mathrm{H}_{24} \mathrm{FN}_{5} \mathrm{O}_{3}$ (545.57): C, 70.45; H, 4.43; F, 3.48; N, 12.84; Found: C, 70.39; H, 4.38; F, 3.43; N, 12.92 .

Acetic-N'-acetyl-2-((3-cyano-4-(4-fluorophenyl)-6-(5,6,7,8-tetrahydronaphthalen-2-yl)pyridin-2-

yl)oxy)acetohydrazonic anhydride (15). A mixture of acetohydrazide 7 (0.416 g, 0.001 mol) and acetic anhydride $(5 \mathrm{~mL})$ was heated at reflux for $6 \mathrm{~h}$. After cooling, the reaction mixture was treated with ethanol and the formed precipitate was filtered, washed with ethanol. The dried crude product was crystallized from EtOH/DMF to give 15.

Yield \% 80; colorless crystals; m.p.200-202 ${ }^{\circ} \mathrm{C}$; IR spectrum $\left(\mathrm{KBr}, \mathrm{cm}^{-1}\right)$ : 3301 (NH), 2938 (CH, alicyclic), 2224 (CN), 1742 (acetoxy C=O), 1670 (amide C=O), 1590 (C=N), 1204 (C-F); ${ }^{1} \mathrm{HNMR}$ (300MHz, DMSO-d,$\delta$ ppm): 1.71 (br. s, $4 \mathrm{H}, 2 \mathrm{CH}_{2}$ of tetrahydronaphthalene), $2.34\left(\mathrm{~s}, 3 \mathrm{H}, \mathrm{NHCO}-\underline{\mathrm{CH}}_{3}\right), 2.35\left(\mathrm{~s}, 3 \mathrm{H}, \mathrm{OCOCH}{ }_{3}\right), 2.72\left(\mathrm{~m}, 4 \mathrm{H}, 2 \mathrm{CH}_{2}\right.$ of tetrahydronaphthalene), $5.69\left(\mathrm{~s}, 2 \mathrm{H}, \mathrm{CH}_{2}\right), 7.12(\mathrm{~d}, \mathrm{~J} 7.8 \mathrm{~Hz}, 1 \mathrm{H}, \mathrm{Ar}-\mathrm{H}), 7.39(\mathrm{t}, J 8.7 \mathrm{~Hz}, 2 \mathrm{H}, \mathrm{Ar}-\mathrm{H}), 7.68(\mathrm{~s}, 1 \mathrm{H}, \mathrm{Ar}-$ $\mathrm{H})$, 7.73-7.80 (m, 4H, Ar-H+Pyridine-H5), 10.59 (s, $1 \mathrm{H}, \mathrm{NH}$ exchangeable with $\left.\mathrm{D}_{2} \mathrm{O}\right) ;{ }^{13} \mathrm{C} \mathrm{NMR}(101 \mathrm{MHz}, \mathrm{DMSO})$

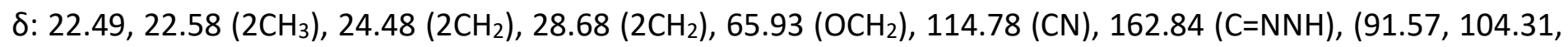
$115.77,115.98,124.72,128.25,129.37,129.74,131.19,131.59,133.29,136.24,137.22,156.44,157.48$, 163.31, 164.41) (18C, Ar-C), 168.63, 170.78 (2C=O); MS, m/z (\%): $500.23\left(\mathrm{M}^{+}, 14\right), 458.40$ (9), $385.18(23.44)$, 344.15 (33.16), 98.02 (57.31), 56.08 (100); Analysis Calcd. for $\mathrm{C}_{28} \mathrm{H}_{25} \mathrm{FN}_{4} \mathrm{O}_{4}$ (500.53), C, 67.19; $\mathrm{H}, 5.03 ; \mathrm{F}, 3.80 ; \mathrm{N}$, 11.19; Found: C, 67.08; H, 4.95; F, 3.74; N, 11.28.

$N^{\prime}$-(2-((3-Cyano-4-(4-fluorophenyl)-6-(5,6,7,8-tetrahydronaphthalen-2-yl)pyridin-2-

yl)oxy)acetyl)benzohydrazide (17). A mixture of hydrazide 7 (0.416 g, $0.001 \mathrm{~mol}$ ) and benzoyl chloride 16 ( $0.1405 \mathrm{~g}, 0.001 \mathrm{~mol})$ in $10 \mathrm{~mL}$ pyridine was heated at reflux for $24 \mathrm{~h}$ then cooled and poured onto ice/water acidified with $\mathrm{HCl}$. The obtained solid was filtered off, washed with water, dried and crystalized from EtOH/DMF to give the benzohydrazide derivative 17.

Yield 81\%; pale yellow crystals; m.p. 272-274 ${ }^{\circ} \mathrm{C}$; IR ( $\left.\mathrm{KBr}, \mathrm{cm}^{-1}\right)$ : 3432, $3230(2 \mathrm{NH}), 2925$ (CH, alicyclic), 2222 (CN), 1728, 1716 (2C=O), 1607 (C=N), 1232 (C-F); ${ }^{1} \mathrm{H}$ NMR (300MHz, DMSO-d, $\left.8 p p m\right): 1.77$ (br s, 4H, 2CH $\mathrm{CH}$ tetrahydronaphthalene), $2.81\left(\mathrm{~m}, 4 \mathrm{H}, 2 \mathrm{CH}_{2}\right.$ of tetrahydonaphthalene), $5.22\left(\mathrm{~s}, 2 \mathrm{H}, \mathrm{OCH}_{2}\right), 7.16(\mathrm{~d}, \mathrm{~J}=8.4 \mathrm{~Hz}$, $1 \mathrm{H}, \mathrm{Ar}-\mathrm{H}), 7.45-7.51(\mathrm{~m}, 5 \mathrm{H}, \mathrm{Ar}-\mathrm{H}), 7.81-7.99(\mathrm{~m}, 7 \mathrm{H}, \mathrm{Ar}-\mathrm{H}+$ Pyridine-H5), 10.37 (s, $1 \mathrm{H}, \mathrm{NH}$ exchangeable with $\left.\mathrm{D}_{2} \mathrm{O}\right), 10.46$ (s, $1 \mathrm{H}, \mathrm{NH}$ exchangeable with $\left.\mathrm{D}_{2} \mathrm{O}\right) ;{ }^{13} \mathrm{C} \mathrm{NMR}(101 \mathrm{MHz}, \mathrm{DMSO}) \delta: 21.57,22.61\left(2 \mathrm{CH}_{2}\right), 28.55,29.18$ $\left(2 \mathrm{CH}_{2}\right), 65.98\left(\mathrm{OCH}_{2}\right), 115.78(\mathrm{CN}),(95.04,108.72,116.59,123.29,127.45,128.48,129.10,130.61,130.97$, 133.11, 135.17, 136.76, 155.02, 155.64, 162.96) (23 C, Ar-C), 165.36, 168.08 (2 C=O); MS, m/z (\%): 521.18 $\left(\mathrm{M}^{+}+1,2\right), 520.19\left(\mathrm{M}^{+}, 5\right), 519.26\left(\mathrm{M}^{+}-1,2\right), 516.20(2), 515.12$ (3), 514.12 (2), 445.14 (37), 444.14 (100); Analysis calcd. for: $\mathrm{C}_{31} \mathrm{H}_{25} \mathrm{FN}_{4} \mathrm{O}_{3}$ (520.19): C, 71.53; $\mathrm{H}, 4.84 ; \mathrm{F}, 3.65 ; \mathrm{N}, 10.76$; Found: $\mathrm{C}, 71.41 ; \mathrm{H}, 4.78 ; \mathrm{F}, 3.59 ; \mathrm{N}$, 10.88.

\section{2-((3-Cyano-4-(4-fluorophenyl)-6-(5,6,7,8-tetrahydronaphthalen-2-yl)pyridin-2-yl)oxy)-N'-formylaceto-}

hydrazide (19). A mixture of $7(0.832 \mathrm{~g}, 0.002 \mathrm{~mol})$ and formic acid $17(10 \mathrm{~mL})$ was heated at reflux for $6 \mathrm{~h}$. The 
resulting solid on heating was collected by filtration, washed with hot ethanol, dried and recrystallized from ethanol/DMF to give 19.

Yield 78\%; off white crystals; m.p:244-246 ${ }^{\circ} \mathrm{C}$; IR ( $\left.\mathrm{KBr}, \mathrm{cm}^{-1}\right): 3440$ (br, NH), 2922 (CH, alicyclic), 2220 (CN), 1724 (C=O), 1622 (C=O), 1247 (C-F); ${ }^{1} \mathrm{HNMR}\left(400 \mathrm{MHz}, \mathrm{DMSO}-\mathrm{d}_{6}, \delta p p m\right)$ : 1.76 (br.s, 4H, 2CH of tetrahydronaphthalene), 2.77 (br.s, $4 \mathrm{H}, 2 \mathrm{CH}_{2}$ of tetrahydronaphthalene), $5.08\left(\mathrm{~s}, 2 \mathrm{H}, \mathrm{OCH}_{2}\right), 7.15(\mathrm{~d}, J 8.0 \mathrm{~Hz}$, $1 \mathrm{H}, \mathrm{Ar}-\mathrm{H}), 7.44(\mathrm{t}, J 8.0 \mathrm{~Hz}, 2 \mathrm{H}, \mathrm{Ar}-\mathrm{H}), 7.81-7.91(\mathrm{~m}, 5 \mathrm{H}, \mathrm{Ar}-\mathrm{H}+$ Pyridine-H5), 8.04 (s, 1H, - $\underline{\mathrm{C}}=\mathrm{O}$ aldehydic proton), 10.23, $10.51\left(2 \mathrm{~s}, 2 \mathrm{NH}\right.$, exchangeable with $\left.\mathrm{D}_{2} \mathrm{O}\right),{ }^{13} \mathrm{C} \mathrm{NMR}(101 \mathrm{MHz}, \mathrm{DMSO}) \delta: 22.48\left(2 \mathrm{CH}_{2}\right), 28.72$ $\left(2 \mathrm{CH}_{2}\right), 65.50\left(\mathrm{OCH}_{2}\right), 115.75(\mathrm{CN}),(97.13,107.43,115.96,123.48,128.04,129.48,131.08,131.17,133.50$, 136.57, 137.23, 154.45, 155.29, 163.00) (17C, Ar-C),161.63, 169.70 (2C=0); MS, m/z (\%): $445.15\left(M^{+}+1,2\right)$, $444.12\left(\mathrm{M}^{+}, 7\right), 403.08$ (20), 402.08 (100), 358.11 (26), 357.09 (95), 344.20 (26), 343.06 (22); Analysis Calcd. for $\mathrm{C}_{25} \mathrm{H}_{21} \mathrm{FN}_{4} \mathrm{O}_{3}$ (444.47): C, 67.56; $\mathrm{H}, 4.76 ; \mathrm{F}, 4.27 ; \mathrm{N}, 12.61$; Found: $\mathrm{C}, 67.58 ; \mathrm{H}, 4.69 ; \mathrm{F}, 4.23 ; \mathrm{N}, 12.68$

Methyl2-(2-((3-cyano-4-(4-fluorophenyl)-6-(5,6,7,8-tetrahydronaphthalen-2-yl)pyridin-2-yl)oxy)acetyl)-

hydrazine-1-carbodithioate (20). To a mixture of acetohydrazide $7(0.416 \mathrm{~g}, 0.001 \mathrm{~mol})$ and triethylamine $(0.14 \mathrm{~mL}, 0.001 \mathrm{~mol})$ in ethanol $(15 \mathrm{~mL})$, carbon disulfide $(0.80 \mathrm{~mL}, 0.001 \mathrm{~mol})$ was added dropwise. Methyl iodide $(0.062 \mathrm{~mL}, 0.001 \mathrm{~mol})$ was then added and the reaction mixture was stirred at room temperature for $30 \mathrm{~min}$. Water $(50 \mathrm{~mL})$ was then added and the formed precipitate was filtered off, washed with water, dried and recrystallized from EtOH/DMF to give 20.

Yield 68\%; light brown crystals; m.p: 210-212 ${ }^{\circ} \mathrm{C}$; IR ( $\left.\mathrm{KBr}, \mathrm{cm}^{-1}\right): 3439$ (NH), 2925 (CH, alicyclic), 2219 (CN), $1717(\mathrm{C}=\mathrm{O}), 1624(\mathrm{C}=\mathrm{N}), 1232$ (C-F); ${ }^{1} \mathrm{HNMR}\left(300 \mathrm{MHz}, \mathrm{DMSO}-\mathrm{d}_{6}, \delta p p m\right)$ : 1.76 (br.s, 4H, 2CH $\mathrm{H}_{2}$ of tetrahydronaphthalene), $2.56\left(\mathrm{~s}, 3 \mathrm{H}, \mathrm{SCH}_{3}\right), 2.76$ (br.s, $4 \mathrm{H}, 2 \mathrm{CH}_{2}$ of tetrahydronaphthalene), 5.16, 5.46 (2s, $2 \mathrm{H}$, $\left.\mathrm{OCH}_{2}\right), 7.15(\mathrm{~d}, J=8.1 \mathrm{~Hz}, 1 \mathrm{H}, \mathrm{Ar}-\mathrm{H}), 7.44(\mathrm{t}, J=8.7 \mathrm{~Hz}, 2 \mathrm{H}, \mathrm{Ar}-\mathrm{H}), 7.78-7.90(\mathrm{~m}, 5 \mathrm{H}, \mathrm{Ar}-\mathrm{H}+$ Pyridine-H5), 10.69 $\left(\mathrm{s}, 1 \mathrm{H}, \mathrm{NH}\right.$, exchangeable with $\left.\mathrm{D}_{2} \mathrm{O}\right), 10.75\left(\mathrm{~s}, 1 \mathrm{H}, \mathrm{NH}\right.$, exchangeable with $\left.\mathrm{D}_{2} \mathrm{O}\right) ;{ }^{13} \mathrm{C} \mathrm{NMR}(101 \mathrm{MHz}, \mathrm{DMSO}) \delta$ : $19.56\left(\mathrm{SCH}_{3}\right), 22.49\left(2 \mathrm{CH}_{2}\right), 28.72,29.74\left(2 \mathrm{CH}_{2}\right), 64.30\left(\mathrm{OCH}_{2}\right), 113.55(\mathrm{CN}),(93.84,105.54,115.98,122.39$, $128.82,129.10,131.15,132.28,134.91,136.43,137.19,155.98,158.06,163.11,164.07)$ (17C, Ar-C), 168.14 (C=O), $201.65(\mathrm{C}=\mathrm{S}) ; \mathrm{MS}, \mathrm{m} / \mathrm{z}(\%): 510.68\left(\mathrm{M}^{+}+4,52.52\right), 506.30\left(\mathrm{M}^{+}, 100\right)$; Analysis calcd. for: $\mathrm{C}_{26} \mathrm{H}_{23} \mathrm{FN}_{4} \mathrm{O}_{2} \mathrm{~S}_{2}$ (506.61): C, 61.64; H, 4.58; F, 3.75; N, 11.06; S, 12.66; Found: C, 61.56; H, 4.49; F, 3.67; N, 11.19; S, 12.64.

\section{2-(2-(3,5-Dimethyl-1H-pyrazol-1-yl)-2-oxoethoxy)-4-(4-fluorophenyl)-6-(5,6,7,8-tetrahydronaphthalen-2-}

yl)nicotinonitrile (23). A mixture of acetohydrazide 7 (0.416 g, $0.001 \mathrm{~mol})$ and acetyl acetone 20 (2 mL) was heated at reflux for $12 \mathrm{~h}$. After cooling the fused mixture was treated with ethanol and filtered. The crude product was crystallized from ethanol to give compound 23.

Yield: 65 \%; Light brown crystals; m.p.: 190-192 ${ }^{\circ} \mathrm{C}$; IR spectrum (KBr, cm$\left.{ }^{-1}\right): 2929$ (CH, alicyclic), 2219 (CN), $1726(\mathrm{C}=\mathrm{O}), 1594(\mathrm{C}=\mathrm{N}), 1227(\mathrm{C}-\mathrm{F})$; ${ }^{1} \mathrm{HNMR}\left(400 \mathrm{MHz}, \mathrm{DMSO}-\mathrm{d}_{6}, \delta \mathrm{ppm}\right): 1.76\left(\mathrm{~m}, 4 \mathrm{H}, 2 \mathrm{CH}_{2}\right.$ of tetrahydronaphthalene), $2.29\left(\mathrm{~s}, 3 \mathrm{H}, \mathrm{CH}_{3}\right), 2.45$ (s, 3H, $\left.\mathrm{CH}_{3}\right), 2.72$ (br. s, $4 \mathrm{H}, 2 \mathrm{CH}_{2}$ of tetrahydronaphthalene), $5.90\left(\mathrm{~s}, 2 \mathrm{H}, \mathrm{OCH}_{2}\right), 6.35$ (s, $1 \mathrm{H}, \mathrm{CH}$ pyrazole), 7.05 (d, J $\left.8.0 \mathrm{~Hz}, 1 \mathrm{H}, \mathrm{Ar}-\mathrm{H}\right), 7.46(\mathrm{t}, J 8.0 \mathrm{~Hz}, 2 \mathrm{H}, \mathrm{Ar}-\mathrm{H}), 7.60(\mathrm{~s}, 1 \mathrm{H}$, $\mathrm{Ar}-\mathrm{H}), 7.68(\mathrm{~d}, J 8.0 \mathrm{~Hz}, 1 \mathrm{H}, \mathrm{Ar}-\mathrm{H}), 7.69-7.87\left(\mathrm{~m}, 3 \mathrm{H}, \mathrm{Ar}-\mathrm{H}+\right.$ pyridine-H5); ${ }^{13} \mathrm{C} \mathrm{NMR}(101 \mathrm{MHz}, \mathrm{DMSO}) \delta: 13.56$, $13.60\left(2 \mathrm{CH}_{3}\right), 22.50\left(2 \mathrm{CH}_{2}\right), 28.61\left(2 \mathrm{CH}_{2}\right), 68.55\left(\mathrm{OCH}_{2}\right), 113.31(\mathrm{CN}),(92.26,102.64,110.31,115.77,115.98$, 121.57, 127.72, 129.80, 129.80, 131.12, 132.76, 134.30, 135.65, 136.71, 150.45, 154.54, 156.53, 159.39, 163.83, 165.99) (20C, Ar-C), 168.16 (C=O); MS, m/z (\%): $482.25\left(\mathrm{M}^{+}+2,5\right), 480.79\left(\mathrm{M}^{+}, 9\right), 478.74\left(\mathrm{M}^{+}-2,7\right)$, 292.15 (26), 210.13 (100), 57.11 (42); Analysis Calcd. For $\mathrm{C}_{29} \mathrm{H}_{25} \mathrm{FN}_{4} \mathrm{O}_{2}$ : (480.54), C, 72.48; H, 5.24; F, 3.95; N, 11.66; Found: C, 72.35; H, 5.19; F, 3.89; N, 11.73 .

N-(2-(2-((3-Cyano-4-(4-fluorophenyl)-6-(5,6,7,8-tetrahydronaphthalen-2-yl)pyridin-2-yl)oxy)acetyl)-5-oxo2,5-dihydro-1H-pyrazol-3-yl)acetamide (26). To a solution of acetohyrazide 7 (0.416 g, $0.001 \mathrm{~mol})$ in $10 \% \mathrm{KOH}$ solution $(10 \mathrm{~mL})$, ethyl cyanoacetate $3(0.113 \mathrm{~g}, 0.001 \mathrm{~mol})$ was refluxed in absolute ethanol (20 $\mathrm{ml})$ for $10 \mathrm{~h}$, then glacial acetic acid $(5 \mathrm{~mL})$ was added and the reaction mixture was heated at reflux for another $2 \mathrm{~h}$. The 
solid obtained upon cooling, dilution with water, acidification with conc. $\mathrm{HCl}$ and leaving in the fridge till next day was filtered, washed with water, dried and crystallized from acetic acid.

Yield 76\%; off colorless crystals; m. p. 298-300 ㄷ; IR spectrum (KBr, cm-1): $3440(\mathrm{OH}), 3196(\mathrm{NH}), 2926(\mathrm{CH}$, alicyclic), 2218 (CN), 1606 (br 2 C=O), 1230 (C-F); 1HNMR (300 MHz, DMSO-d6, oppm): 1.77 (br. s, 4H, 2CH2 of tetrahydronaphthalene), $1.87\left(\mathrm{~s}, 3 \mathrm{H}, \mathrm{COCH}_{3}\right), 2.78\left(\mathrm{~m}, 4 \mathrm{H}, 2 \mathrm{CH}_{2}\right.$ of tetrahydronaphthalene), $5.11\left(\mathrm{~s}, 2 \mathrm{H}, \mathrm{OCH}_{2}\right)$, 7.18 (d, J 8.4 Hz, 1H, Ar-H), 7.42-7.95 (m, 8H, Ar-H, CH-pyrazoleand Pyridine-H5), 9.89 (s, 1H, NH exchangeable with $\left.\mathrm{D}_{2} \mathrm{O}\right), 10.21\left(\mathrm{~s}, 1 \mathrm{H}, \mathrm{OH}\right.$ exchangeable with $\left.\mathrm{D}_{2} \mathrm{O}\right) ;{ }^{13} \mathrm{CNMR}(101 \mathrm{MHz}, \mathrm{DMSO}) \delta: 20.90\left(\mathrm{CH}_{3}\right), 23.03,23.10$ $\left(2 \mathrm{CH}_{2}\right), 28.69,29.26\left(2 \mathrm{CH}_{2}\right), 64.26\left(\mathrm{OCH}_{2}\right), 114.29(\mathrm{CN}),(92.28,93.02,106.69,116.48,123.83,128.71,129.96$, 131.62, 132.67, 134.00, 136.02, 137.72, 140.44, 155.62, 157.61 163.58, 164.85) (19C, Ar-C), $166.49,168.35$ (2 $\mathrm{C}=0) ; \mathrm{MS}, \mathrm{m} / \mathrm{z}(\%): 525.35\left(\mathrm{M}^{+}, 5\right), 385.15(30), 357.16$ (33), $85.10(24), 74.12$ (100); Analysis Calcd. for: $\mathrm{C}_{29} \mathrm{H}_{24} \mathrm{FN}_{5} \mathrm{O}_{4}$ (525.54):C, 66.28; $\mathrm{H}, 4.60 ; \mathrm{F}, 3.62 ; \mathrm{N}, 13.33$; Found: $\mathrm{C}, 66.19 ; \mathrm{H}, 4.53 ; \mathrm{F}, 3.58 ; \mathrm{N}, 13.39$.

\section{2-(5-(((3-Cyano-4-(4-fluorophenyl)-6-(5,6,7,8-tetrahydronaphthalen-2-yl)pyridin-2-yl)oxy)methyl)-1,3,4-}

oxadiazol-2(3H)-ylidene)malononitrile (30). A mixture of the acetohydrazide $7(0.416 \mathrm{~g}, 0.001 \mathrm{~mol})$ and [bis(methylthio)methylene]-malononitrile $(0.174 \mathrm{~g}, 0.001 \mathrm{~mol})$, in absolute ethanol $(30 \mathrm{~mL})$ was heated at reflux for $12 \mathrm{~h}$. The crystalline precipitate so formed under reflux was filtered off, washed with hot ethanol and crystallized from DMF to give the 1,3,4-oxadiazole 30.

Yield 76\%; Orange crystals; m.p. > $340{ }^{\circ} \mathrm{C}$; IR spectrum $\left(\mathrm{KBr}, \mathrm{cm}^{-1}\right): 3172(\mathrm{NH}), 2926(\mathrm{CH}$, alicyclic), 2219 (CN), $1614(\mathrm{C}=\mathrm{N}), 1228$ (C-F), 1141 (C-O-C); ${ }^{1} \mathrm{H}$ NMR (300 MHz, DMSO-d,$\left.\delta \mathrm{ppm}\right): 1.63\left(\mathrm{~m}, 4 \mathrm{H}, 2 \mathrm{CH}_{2}\right.$ of tetrahydronaphthalene), $2.72\left(\mathrm{~m}, 4 \mathrm{H}, 2 \mathrm{CH}_{2}\right.$ of tetrahydronaphthalene), 5.13, 4.87, $5.26\left(3 \mathrm{~s}, 2 \mathrm{H}, \mathrm{OCH}_{2}\right), 6.81$, 6.98, $7.07(3 \mathrm{~d}, J 7.5 \mathrm{~Hz}, J 8.1 \mathrm{~Hz}, J=8.1 \mathrm{~Hz}, 1 \mathrm{H}, \mathrm{C}-4$ of tetrahydronaphthalene), 7.44-7.54 (m, 3H, Ar-H), 7.70$7.90\left(\mathrm{~m}, 4 \mathrm{H}, \mathrm{Ar}-\mathrm{H}+\right.$ Pyridine-H5), 9.48, 10.46, 10.49 (3s, $1 \mathrm{H}, \mathrm{NH}$ oxadiazole, exchangeable with $\left.\mathrm{D}_{2} \mathrm{O}\right) ;{ }^{13} \mathrm{C} \mathrm{NMR}$

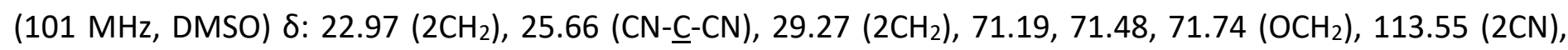
113.98 (CN), (93.60, 109.75, 116.32, 122.41, 126.60, 126.39, 127.78, 128.46, 130.91, 133.44, 134.28, 135.34, 136.09, 155.95, 156.78, 163.84, 164.48) (17C, Ar-C), 157.82 (C5 of oxadiazole), 208.62 (C2 of oxadiazole); MS: m/z (\%): $490.50\left(\mathrm{M}^{+}, 26\right), 358.15$ (64), 357.14 (66), 344.13 (100), 343.12 (94.86); Analysis Calcd. for $\mathrm{C}_{28} \mathrm{H}_{19} \mathrm{FN}_{6} \mathrm{O}_{2}$ (490.50): C, 68.56; H, 3.90; F, 3.87; N, 17.13; Found: C, 68.49; H, 3.87; F, 3.83; N, 17.21.

\section{In-vitro anticancer activities}

The cytotoxicity activities on HCT116 (colorectal carcinoma) and MCF-7 (human breast adenocarcinoma) human cell lines was assessed using the 3-[4,5-dimethyl-2-thiazolyl)-2,5-diphenyl-2H-tetrazolium bromide (MTT) assay. ${ }^{46-48}$ These cancer cell lines were purchased from ATCC (Rockville, MD, USA). The cells were cultured in a 96-well sterile microplate $\left(5 \times 10^{4}\right.$ cells per well) at $37^{\circ} \mathrm{C}$ in Dulbecco's Modified Eagle's medium (DMEM) supplemented with $10 \%$ heat-inactivated fetal bovine serum (FBS) and $100 \mathrm{U} / \mathrm{mL}$ of both penicillin and streptomycin in a $5 \% \mathrm{CO}_{2}$ humidified atmosphere. After 24 hours, the media were removed and a fresh serum-free medium (90 uL / well) were added together with $10 \mathrm{uL}$ of series of each compound or doxorubicin ${ }^{\circledR}$ (positive control) concentrations in DMSO for 48 hours. Then, media were removed, MTT ( $40 \mu \mathrm{L}$ of $2.5 \mathrm{mg} / \mathrm{mL}$ ) was added to each well and incubated for 4 hours. $200 \mu \mathrm{L}$ of DMSO were added to solubilize the formazan dye crystals (purple color). Using a SpectraMax ${ }^{\circledR}$ Paradigm ${ }^{\oplus}$ Multi-Mode microplate reader, the absorbance was measured at $570 \mathrm{~nm}$. Each experiment was repeated on three different days and conducted in triplicate. The relative cell cytotoxicity was measured according to the following equation:

\section{$\%$ cytotoxicity $=\left(1-A_{s} / A_{b}\right) * 100$}

Where; $A_{s}=$ Absorbance of each sample and $A_{b}=$ Absorbance of the blank. The probit analysis using the SPSS software program (version 20, SPSS Inc., Chicago, IL, USA) was used to determine each IC 50. 


\section{Acknowledgements}

The authors thank the management and the authorities of National Research Centre, Dokki, Cairo, Egypt, for their kind support and constant encouragement. The authors are gratefully acknowledge the school of Chemical Engineering at Aalto University, Finland and German Research Foundation (DFG), Germany for performing NMR analyses.

\section{Supplementary Material}

Supplementary material related to this article, including Nuclear Magnetic Resonance (1H and $13 \mathrm{C} \mathrm{NMR)}$ figures for compounds 8b; 8c; 8d; 8e; 11c; 11d; 15; 17 and 23 are available in the online version of the text.

\section{References}

1. Zhang, J. Y. Nat. Rev. Drug Disc. 2002, 1, 101-102.

https://doi.org/10.1038/nrd742

2. Buolamwini, J. K. Curr. Opin. Chem. Biol. 1999, 3, 500-509.

https://doi.org/10.1016/S1367-5931(99)80073-8

3. Androutsopoulos, V. P. ; Spandidos, D. A. Oncol Rep. 2018, 39(2), 519-524.

4. Xie, W.; Xie, S.; Zhou, Y.; Tang, X.; Liu, J.; Yang, W.; Qiu, M. Eur. J. Med. Chem.2014, 81, $22-27$. https://doi.org/10.1016/j.ejmech.2014.05.001

5. Sajith, A. M.; Abdul Khader, K. K.; Joshi, N.; Reddy, M. N.; Syed, Ali Padusha, M.; Nagaswarupa, H. P.; Nibin Joy, M.; Bodke, Y. D.; Karuvalam, R. P.; Banerjee, R.; Muralidharan, A.; Rajendra, P. Eur. J. Med. Chem., 2015, 89, 21-31.

https://doi.org/10.1016/i.ejmech.2014.10.037

6. Thapa, P.; Kadayat, T. M.; Park, S.; Shin, S.; ThapaMagar, T. B.; Bist, G.; Shrestha, A.; Na, Y.; Kwon, Y.; Lee, E. S. Bioorg. Med. Chem., 2016, 66, 145-159.

https://doi.org/10.1016/j.bioorg.2016.04.007

7. Henkel, T.; Brunne, R. M.; Müller, H.; Reichel, F. Angew. Chem. Int. Ed. Engl 1999, 38, 643-647. https://doi.org/10.1002/(SICI)1521-3773(19990301)38:5<643::AID-ANIE643>3.0.CO;2-G

8. Santos, V. A. F. F. M.; Regasini, L. O.; Nogueira, C. R.; Passerini, G. D.; Martinez, I.; Bolzani, V. S.; Graminha, M. A. S.; Cicarelli, R. M. B.; Furlan M. J. Nat. Prod 2012, 75, 991-995.

https://doi.org/10.1021/np300077r

9. Bull, J. A.; Mousseau, J. J.; Pelletier, G.; Charette, A. B. Chem. Rev. 2012, 112, 2642-2713. https://doi.org/10.1021/cr200251d

10. Goetz, A. E.; Garg, N. K. Nature Chem. 2013, 5, 54-60. https://doi.org/10.1038/nchem.1504

11. Henry, G. D. Tetrahedron 2004, 60, 6043-6061. https://doi.org/10.1016/j.tet.2004.04.043

12. Barker, M.; Clackers, M.; Copley, R.; Demaine, D.A.; Inglis, G.G.A.; Johnston, M. J.; Jones, H.T.; Haas, M.V.; House, D.; Loiseau, R.; et al. J. Med. Chem. 2006, 49, 4216-4231. 
https://doi.org/10.1021/jm060302x

13. Hamdy, N. A.; Gamal-Eldeen, A. M.; Eur. J. Med. Chem.2009, 44, 4547-4556. https://doi.org/10.1016/i.ejmech.2009.06.023

14. Dong, Y.Z.; Shi, Q.; Nakagawa-Goto, K.; Wu, P.C.; Bastow, K.F.; Morris-Natschke, S.L.; Lee, K.H. Bioorg. Med. Chem. Lett. 2009, 19, 6289-6292.

https://doi.org/10.1016/i.bmcl.2009.09.092

15. Zaghary, W.A. Bull. Fac. Pharm. Cairo Univ. 2007, 45, 391-400.

16. Ates-Alagoz, Z.; Yildiz, S.; Buyukbingol, E. Chemotherapy 2007, 53, 110-113. https://doi.org/10.1159/000100011

17. Li, X.-N.; Lei, C.; Yang, L.-M.; Li, H.-M.; Huang, S.-X.; Du, X.; Pu, J.-X.; Xiao, W.-L.; Zheng, Y.-T.; Sun, H.-D. Fitoterapia, 2012, 83, 249-252.

https://doi.org/10.1016/i.fitote.2011.11.006

18. Al-Abdullah, E.S. Molecules 2011, 16, 3410-3419.

https://doi.org/10.3390/molecules 16043410

19. Monneret, C. Eur. J. Med. Chem. 2001, 36,483-493.

https://doi.org/10.1016/S0223-5234(01)01244-2

20. Mohamed, M. F.; Darweesh, A. F.; Elwahy, A. H. M.; Abdelhamid, I. A. RSC Adv 2016, 6, 40900-40910. https://doi.org/10.1039/C6RA04974E

21. Sanad, S. M. H.; Kassab, R. M.; Abdelhamid, I. A.; Elwahy, A. H. M. Heterocycles 2016, 92, 910-924. https://doi.org/10.3987/COM-16-13441

22. Abdelhamid, I. A.; Darweesh, A. F.; Elwahy, A. H. M. Tetrahedron Lett. 2015, 56, 7085-7088. https://doi.org/10.1016/j.tetlet.2015.11.015

23. Kassab, R. M.; Elwahy, A. H. M.; Abdelhamid, I. A. Monatshefte Für Chemie - Chem Mon 2016, 147, 12271232.

https://doi.org/10.1007/s00706-015-1644-z

24. Hebishy, A.M.S.; Abdelhamid, I.A.; Elwahy, A.H.M. Arkivoc 2018, v, 97-108. https://doi.org/10.24820/ark.5550190.p010.367

25. Hebishy, A.M.S.; Abdelhamid, I.A.; Elwahy, A.H.M. Arkivoc 2018, v, 109-123. https://doi.org/10.24820/ark.5550190.p010.498

26. Gamal-Eldeen, A. M.; Hamdy, N. A.; Abdel-Aziz, H. A.; El-Hussieny, E. A.; Fakhr, I. M. I. Eur. J. Med. Chem. 2014, 77, 323-333.

https://doi.org/10.1016/i.ejmech.2014.03.021

27. Hamdy, N. A.; Gamal-eldeen, A. M., Abdelaziz, H. A.; Fakhr, I M. I.; Eur. J. Med. Chem. 2010, 45, 463-470. https://doi.org/10.1016/i.ejmech.2009.10.027

28. Hamdy, N. A.; Anwar, M. M.; Abu-zied, K. M.; Awad, H. M. Acta Pol. Pharm. 2013, 70, 987-1001.

29. Hamdy, N. A. Egypt J. Chem. 2005, 48, 749-758.

30. Allinger, N.L.; Jones, E.S. J. Org. Chem. 1962, 27, 70-76. https://doi.org/10.1021/jo01048a018

31. Amin, K. M.; El-Zahar, M. I.; Anwar, M. M.; Kamel, M. M.; Mohamed, M. H. Acta Pol. Pharm. 2009, 66, 279-291.

32. Sruthy, M. P., Meena Chandran, Krishnakumar, K. Int. J. Med. Chem. Anal. IJMCA 2016, 6, 56-60.

33. Arief, M. M. H.; Aly, A. A.; Khalil, A. A.; Mohamed, H. I.; J. Chem. Pharm. Res., 2014, 6, 327-331.

34. Palla, G.; Predieri, G.; Domiano, P.; Tetrahedron 1986, 42, 3649-3654. 
35. Demirbas, A. Turk. J. Chem. 2004, 28, 311-323. https://doi.org/10.1260/0309524041590143

36. Demirbas, N.; Karaoglu, S.A.; Demirbas, A.; Sancak, K. Eur. J. Med. Chem. 2004, 39, 793-804. https://doi.org/10.1016/i.eimech.2004.06.007

37. Wyrzykiewicz, E.; Prukah, D. J. Heterocycl. Chem. 1998, 35, 381-387. https://doi.org/10.1002/jhet.5570350221

38. Galic, N.; Peric, B.; Kojic-Prodic, B.; Cimerman, Z. J. Mol. Struct. 2001, 559, 187-194. https://doi.org/10.1016/S0022-2860(00)00703-1

39. Bayrak, H.; Demirbas, A.; Karaoglu, S. A. Demirbas, N. Eur. J. Med. Chem. 2009, 44 1057-1066. https://doi.org/10.1016/j.ejmech.2008.06.019

40. Waghmode, K. T. J. Chem. Pharm. Res., 2014, 6, 1101-1105.

41. Kanase, M. S.;Piste, P. B. Int. J. Pharm. Sci. and Drug Res. 2017, 9(2), 38-43. https://doi.org/10.25004/IJPSDR.2017.090201

42. Dawood, K. M. Farag, A. M. and Abdel-Aziz, H. A. Heteroatom Chemistry 2007, 18(3), 294-300. https://doi.org/10.1002/hc.20298

43. Abd El-All, M. M.; Halawa, A. H.; Hassan, A. A. El-H.; El-Nassag, M. A.; Abd El-Jaleel, G. A. El-R.; Eliwa, E. M.; Bedair, A. H. J. Atoms and Molecules 2013, 3(4), 537-552.

44. Mohamed, F. K. Pelagia Research Library Der Chemica Sinica, 2010, 1, 20-31.

45. Gobis, K.; Foks, H.; Bojanowski, K.; Augustynowicz-Kopec', E.; Napiórkowska, A. Bioorg. Med. Chem. 2012, 20, 137-144.

https://doi.org/10.1016/j.bmc.2011.11.020

46. Abdel Latif, N. A.; Batran, R. Z.; Mohamed, S. F.; Khedr, M. A.; Mohamed Kobeasy, M.; Al- Shehri, S.; Awad, H. M. Mini-Rev Med. Chem. 2018, 18, 1572-1587.

https://doi.org/10.2174/1389557518666180423145246

47. Soliman, H. A.; Kalmouch, A.; Awad, H. M.; Abdel Wahed, N. A. M. Russ. J. Gen. Chem. 2018, 88, 17261733. https://doi.org/10.1134/S1070363218080273

48. Kassem, A. F.; El-Kady, D. S.; Awad, H. M.; El-Sayed, W. A. Mini-Rev Med. Chem. 2018;

49. https://doi.org/10.2174/1389557519666181231121217 